\title{
Old age pensions and retirement in Spain
}

\author{
Raquel Vegas Sánchez • Isabel Argimón • \\ Marta Botella • Clara I. González
}

Received: 22 February 2010 / Accepted: 5 February 2013 / Published online: 16 June 2013

C The Author(s) 2013. This article is published with open access at SpringerLink.com

\begin{abstract}
In this paper we analyze the influence that incentives play in the timing of the transition to retirement in Spain. We use the Continuous Sample of Working Histories 2006 (CSWH "Muestra Continua de Vidas Laborales", in Spanish) to construct incentive measures from the Social Security provisions in relation to retiring at old age. We analyse the role played by such incentives and other socio-economic variables on the retirement hazard of men aged between 60 and 70, using a duration model to carry out a dynamic analysis. We assess the effects of the pension system reform that took place in 2002, which set stricter conditions to access an old pension. The results show that both the pension wealth and the substitution effects play a significant role in retirement decisions, but that, after the reform, the latter effects become less important.
\end{abstract}

Keywords Older workers employment $\cdot$ Retirement $\cdot$ Public pensions

JEL Classification $\quad \mathrm{J} 14 \cdot \mathrm{J} 26$

\section{Introduction}

There has been a decline in the labour force participation of older workers, over the last decades. While in the seventies, the participation rates of males over 55 exceeded $50 \%$,

R. Vegas Sánchez $(\varangle) \cdot$ C. I. González

FEDEA, C/Jorge Juan, 46, 28001 Madrid, Spain

e-mail: rvegas@fedea.es

I. Argimón · C. I. González

Banco de España, Madrid, Spain

M. Botella

Universidad Autónoma de Barcelona, Barcelona, Spain 
in 2008 it did not reach $30 \%$. The role of pension benefits rules in this evolution may have been crucial. These rules may be too generous in providing income support, and they may also create incentives to early retirement. Three characteristics are relevant in this context: the amount of the pension that the system provides, the pattern of benefits associated with each age of retirement, and the entitlement rights that define the conditions to be met to be able to claim a pension at each age.

While many countries have already implemented large reforms, ${ }^{1}$ Spain has mainly undertaken parametric changes in its Social Security system, which have been agreed under the so-called Toledo Agreement. They have been directed to reducing incentives to early retirement and to increasing incentives to leave the labour market at a later age. Active labour force policies that should stimulate the demand for elderly workers have also been proposed with the aim of contributing to raising labour market participation of the elderly. At the end of the day, the effects of pensions on retirement compound labour supply and demand forces, so that their final impact is an empirical issue.

The goal of this paper is to quantify the role that Social Security provisions for oldage pensions play in the retirement decision of Spanish workers and to evaluate the effects of the 2002 reform. We propose to estimate a model for retirement that captures the effects of pension incentives on the timing of the pension claim. In particular, we analyse the probability of claiming a pension at a specific age, given that the worker has not yet retired, as a function, not only of individual demographic characteristics, but also of the economic incentives underlying the retirement legislation.

There is already a large body of research that examines the economic incentives created by the pension system in Spain (see, e.g., Boldrin et al. 1999, 2004; Boldrin and Jimenez-Martín 2007; Jimenez-Martín 2006; Moral-Arce et al. 2009). Our contribution to this field is twofold. First, we exploit the longitudinal information contained in the Continuous Sample of Working Histories (CSWH, "Muestra Continua de Vidas Laborales", MCVL in Spanish), wave 2006, with a duration model. ${ }^{2}$ The detailed information contained in the CSWH, from Spanish Social Security administrative records and that is accompanied by Census data, allows tracking workers' decisions over time so as to take time dependence into account. Moreover, the CSWH has the advantage over other databases used in previous empirical work ${ }^{3}$ that its sample design is publicly known and, therefore, it allows for a better and broader interpretation of the results.

Instead of proposing a point in time estimation, we analyse retirement patterns and the effects of economic incentives using a logistic specification of a duration model. This approach allows the analysis of the role played at each age by incentives stemming from social security rules.

\footnotetext{
1 See Whitehouse et al. (2009) for a recent review of pension reforms in industrialized countries.

2 Moral-Arce et al. (2009) also use the CSWH to evaluate the economic incentives generated by the Social Security System in Spain, but, unlike our work, they carry out such an analysis restricted to a given point in time, 2007.

3 A previous sample of a similar database with information up to 1995 and whose description can be found in Martínez (1999), has been used in Boldrin et al. (1999, 2004), Boldrin and Jimenez-Martín (2007), Jimenez-Martín and Sánchez (2006), and Jimenez-Martín et al. (2006). The main drawbacks of such sample are that the detailed sample design has not been disclosed and that it is not publicly available.
} 
The second contribution of this paper is the quantification of the effect on retirement decisions of the reform that was agreed in 2001 in Spain (Acuerdo para la Mejora y el Desarrollo del Sistema de Protección Social, April 2001) and that was fully implemented in 2002 (Law 35/2002, July). In particular, in this paper, we consider the effects of three main changes (a more detailed description of the reform is provided in Annex 1). ${ }^{4}$ On the one hand, the reform gave access to early retirement before the statutory retirement age established at 65 , for all workers that were at least 61 , had at least 30 years of contributory life ( 2 of which within the last 15 ) and their last employment termination had been involuntary. Up to then, only those who had worked before 1967 were entitled to take early retirement from the age of 60 . On the other hand, the reform increased the linkages between the contributive effort exerted by workers and the pension received, setting the penalty for early retirement decreasing with age and total years of contribution. Moreover, each full year of employment beyond statutory retirement age (65), implied a $2 \%$ increase in the regulatory base to compute retirement benefits, so that those workers older than 65 , with at least 35 years of contributions could receive a pension that exceeded $100 \%$ of the regulatory base value.

We selected a sample of men aged from 60 to 70 in 2006, that had contributed to the Social Security General Scheme and that were entitled to receive retirement benefits. The sample period spans 10 years, from 1996 to 2006. We analyse retirement decisions that imply a full withdrawal from the labour market and that give rise to an old-age pension. ${ }^{5}$ We assimilate the claiming of the pension to the decision to retire for good, whether or not the worker was already discouraged and had stopped looking for a job well before claiming the pension.

The rest of the paper is organized as follows. Section 2 contains a literature survey of the role played by Social Security in the retirement decision of elderly workers, placing special emphasis on the works addressing the Spanish pension system. Section 3 contains the empirical strategy while Sect. 4 describes the dataset used in the empirical analysis. Section 5 summarises the main results and Sect. 6 contains the conclusions. Additionally, two appendixes are included in the paper. Appendix A provides a short explanation about the main features of the Spanish Social Security pension system. Appendix B contains a brief description of the variables used in the empirical analysis and the detailed results of the estimation.

\section{Previous empirical work on the role of Social Security on retirement decisions in Spain}

As mentioned in the previous section, labour force participation rates among older workers and retirement patterns have been extensively analyzed in the literature for Spain; cf. Alba (2007), Boldrin et al. (1999, 2004), Ahn and Mira (2000),

\footnotetext{
4 Another change introduced in 2002 was the regulation of partial retirement which allowed employment and old-age pensions to be simultaneously enjoyed [see Cairó-Blanco (2010) for an analysis of its impact].

5 See Argimón et al. (2007a) for an analysis of different labour status in old age; Argimón et al. (2007a) for the impact of individual demographic characteristics on the likelihood of retirement at each age without considering economic incentives.
} 
Conde-Ruiz and Galasso (2003), Gutiérrez-Domènech (2006). These research documents changes in retirement patterns during the last decades that reflect a trend towards early retirement and lower participation rates among older workers.

An important line of research in Spain is the one devoted to the analysis of the sustainability of the retirement pension system and the reforms needed to reinforce it; cf. Barea (1996), Herce and Alonso-Messeguer (1999), Jimeno and Licandro (1999), Jimeno (2001), Herce et al. (2005), (2009), Messeguer (2006), Balmaseda et al. (2006), Díaz-Gimenez and Díaz-Saavedra (2009a),. The analysis is usually formulated in terms of overlapping generation models. Overall, the available evidence on the effects of delaying the normal retirement age a number of given years shows that it has a favourable impact on the sustainability of the Spanish pension system; cf. MonteroMuñoz (2000), Sánchez-Martín (2003), Boldrin and Jimenez-Martín (2007), DíazGimenez and Díaz-Saavedra (2009b), Sánchez-Martín and Sánchez-Marcos (2008), Conde-Ruiz and González (2012).

Regarding the specific aim of this paper, there is quite a lot of research providing empirical evidence for Spain for the relationship between the incentives embedded in the social security rules and retirement decisions; e.g. Martín and Moreno (1990), Lopez-Garcia (1990), Gómez and Hernandez de Cos (2004). These studies focus on financial determinants to retire (the different rights acquired through age, gender, contributed earnings, years of contribution, pension replacement rates, etc) and the implicit incentives created by the system. The available micro-econometric evidence for Spain shows that the early retirement provisions play an important role in the modal age of retirement and its pattern in different ages (see, e.g., Boldrin et al. 1999,2004) and that, in general, labour force transitions of elderly men depend on Social Security regulations — see Alba (2007), García-Pérez and Sánchez-Martín (2008a,b) ${ }^{6}$, and are correlated with health considerations_-see Blanco (2000); Prieto Rodríguez (2002); and Jimenez-Martín et al. (2006).

Boldrin et al. (1999, 2004) and Jimenez-Martín (2006) conclude that, while economic and financial measures of retirement incentives play some role in explaining retirement behavior, a substantial portion of the latter still remains unexplained and cannot be explained by Social Security factors. Further research by García-Pérez and Sánchez-Martín (2008b) find evidence of the relevance of social security incentives in explaining transitions from unemployment for older workers. Likewise, using a sample of individuals aged between 56 and 70 from the European Union Household Panel (PHOGUE), wave 7 (2000), Utrilla De La Hoz and Ubago (2005) find that a replacement rate (pension over total income) below $80 \%$ reduces the probability of retiring.

As for the impact of minimum pensions, this time based on the estimation of the behavioural parameters of a structural model, Jimenez-Martín and Sánchez (2006, 2007) show that the existence of minimum pension regulation has an impact on early retirement decisions. They find that the combination of age penalties and minimum pensions generate large incentives to early retirement for those workers with low wages and short labour histories. They conclude that there is a threefold increase in

6 García-Pérez and Sánchez-Martín (2008a,b) provide some results on the links between unemployment, retirement and their associated public insurance programmes calibrated with data from the CSWH. 
retirement at 60 with respect to the economy without minimum pensions and total early retirement (before or at 60 ) is almost $50 \%$ larger.

The effect of the successive pension reforms that have taken place in Spain has been empirically addressed in a series of papers. The results point out, in general, to their effectiveness in lowering retirement rates. Jimenez-Martín (2006) carries out a simulation exercise that computes the effect of the Spanish old age pension reforms that took place in 1997 and 2002 and concludes that they reduce the hazard rates. A similar qualitative result is found in Gutiérrez-Domènech (2006), where, using a longitudinal survey of catalan population, it is shown that the 2002 reform contributed to the increase in the probabilities of workers older than 60 to stay employed. On the other hand, Sánchez-Martín (2010), using a calibrated overlapping-generations model, within a general equilibrium framework, finds that the overall effect of the 2002 reform is a clear drop in the average retirement age, as younger cohorts of low income workers benefit from the opportunity of leaving the labour force early. CairóBlanco (2010) analyses partial retirement incentives introduced in 2002 and its impact on the average age of retirement using the option-value framework.

\section{Empirical framework}

This paper follows the hazard-model approach used by many authors, such as Samwick (1998), Gruber and Wise (1999, 2004), and Blundell et al. (2002), which postulate that both Social Security wealth and its evolution in the future are determinants of retirement decisions Gustman and Steinmeier (2008). Although a structural model (Burtless 1986), or applied general equilibrium models (Imrohoroglu et al. 1999) could provide more insight into the decision process, we choose the simplicity of the reduced form technique because of the computational complexity of the alternative approaches. $^{7}$

In particular, the retirement decision is analysed in this paper following a duration model approach, that treats such decision as a dynamic discrete choice, and allows taking into account time dependence. The duration variable (T) for an individual $\mathrm{i}$ is defined as the period that spans from the age the person becomes entitled to receive a retirement pension $\left(e_{i}\right)$ until the age that she claims the benefit $\left(b_{i}\right), t_{i}=$ $\left(b_{i}+1\right)-e_{i}=$. That is, if the person $i$ retires the year she becomes entitled to claim a pension, $\left(\mathrm{e}_{i}=\mathrm{b}_{i}\right)$, we say that her period of survival is 1 . $\mathrm{T}$ is treated as a discrete time-varying variable, defined in years, so that $t_{i} \mathrm{I}[1,6]$. Accordingly, we define the survival function $\mathrm{S}$ at duration $t_{i}$ as the probability that the survival time for individual $\mathrm{i}$ be at least $t_{i}$

$$
S\left(t_{i}\right)=S_{i}=\operatorname{prob}\left(T \geq t_{i}\right)=\prod_{t_{i}=1}^{t_{i}}\left(1-f\left(t_{i}\right)\right.
$$

with $f\left(t_{i}\right)=\operatorname{Pr}\left\{T=t_{i}\right\}$

\footnotetext{
7 See Jimenez-Martín et al. (2006) for a survey of the features of different approaches used in the literature to study the effects of population aging on Social Security expenditures.
} 
Table 1 Distribution by year of birth and retirement age

\begin{tabular}{llllllllr}
\hline Born & 60 & 61 & 62 & 63 & 64 & 65 & Not retired & Total \\
\hline 1936 & & 205 & 199 & 152 & 295 & 892 & 189 & 1,932 \\
1937 & 880 & 201 & 162 & 149 & 295 & 866 & 195 & 2,748 \\
1938 & 817 & 136 & 159 & 153 & 285 & 819 & 170 & 2,539 \\
1939 & 652 & 103 & 135 & 134 & 243 & 732 & 190 & 2,189 \\
1940 & 948 & 168 & 225 & 232 & 401 & 1,225 & 314 & 3,513 \\
1941 & 704 & 140 & 187 & 192 & 332 & 981 & 893 & 3,429 \\
1942 & 607 & 186 & 170 & 188 & 350 & & 1,956 & 3,457 \\
1943 & 600 & 213 & 231 & 205 & & & 2,671 & 3,920 \\
1944 & 554 & 200 & 220 & & & & 2,963 & 3,937 \\
1945 & 546 & 209 & & & & & 3,449 & 4,204 \\
1946 & 388 & & & & & & 3,597 & 3,985 \\
Total & 6,696 & 1,761 & 1,688 & 1,405 & 2,201 & 5,515 & 16,587 & 35,853 \\
Pro Memoria & & & & & & & &
\end{tabular}

Sample of men born between 1936 and 1946 having worked in the General Scheme and with a relation with the Social Security in 2006

Data is right censored as the dataset contains some workers that either can only be observed before they take the decision of interest (i.e. claim pension benefit), because we only observe the individuals up to the year 2006, or did not claim a retirement pension before the age of 66. It is also the case that for some cohorts we can only have observations of people retiring after a given age (60 for those born in 1936) or before a given age (for instance, at most at 60 for those born in 1946) given that this is the age when the sample was extracted, as shown in Table 1.

The hazard function (i.e. the probability of an individual retiring precisely at duration $t_{i}$, given that he has not retired before), is defined as:

$$
\phi\left(t_{i} \mid \mathrm{X}_{\mathrm{i}}\right)=\operatorname{prob}\left\{\mathrm{T}=t_{i} \mid \mathrm{T} \geq \mathrm{t}_{\mathrm{i}}, \mathrm{X}_{\mathrm{i}}\right\}=\operatorname{prob}\left(\mathrm{T}=t_{i} \mid \mathrm{X}_{\mathrm{i}}\right) / \operatorname{prob}\left(\mathrm{T} \geq t_{i} \mid \mathrm{X}_{\mathrm{i}}\right)
$$

where $\mathbf{X}_{i}$ is a vector of explanatory variables, some of which are time dependent, and others are constant and independent of time.

$$
\mathbf{X}_{i}=\left(\mathrm{x}_{1 \mathrm{i}}, \mathrm{x}_{2 \mathrm{i}}, \ldots, \mathrm{x}_{\mathrm{mi}}(\mathrm{t}), \ldots, \mathrm{x}_{\mathrm{ni}}(\mathrm{t})\right)
$$

That is, some of the variables in $\mathrm{X}$, such as the ones related with working status or the measures of incentive mechanisms that are standard in this literature, are timevarying covariates while others, contain information about time-invariant individual characteristics.

Notice that in discrete time, the survival function can be written in terms of the hazards at prior periods,

$$
\mathrm{S}_{\mathrm{k}}=\left(1-\phi_{1}\right) *\left(1-\phi_{2}\right) * \cdots *\left(1-\phi_{k-1}\right)=\prod_{t_{1}=1}^{k-1}\left(1-\phi_{t_{1}}\right)
$$


Let's say that $\mathrm{n}$ is the number of individuals we observed retiring at $\mathrm{t}=\mathrm{k}$, and $\mathrm{r}-\mathrm{n}$ the number of individuals that continue working at $\mathrm{t}=\mathrm{k}$ (censored data in retirement). Therefore the likelihood function in this case can be expressed as:

$$
\begin{aligned}
\mathcal{L} & =\prod_{i=1}^{n} \operatorname{Prob}(T=k) \prod_{j=1}^{c} \operatorname{Prob}(T>k) \\
& =\prod_{i=1}^{n}\left(\phi_{k} * S_{(k-1)}\right) * \prod_{i=1}^{r-n} S_{(k)}
\end{aligned}
$$

\section{The data}

\subsection{The CSWH}

The database Continuous Sample of Working Histories (CSWH 2006) contains the working and contributory-pension history of more than one million individuals, whose anonymity is preserved. It is a $4 \%$ random sample from a reference population, which is composed of all the people who at any time during 2006 had a registered record with the Social Security system, either because they were contributing or because they were receiving a pension. While unemployed workers are included, as the National Employment Service pays their social contributions to the Social Security Funds, civil servants (public sector employment) are not, ${ }^{8}$ as there is no information on the Clases Pasivas scheme.

The data contain, for each employment spell, information on covered earnings, which are the amount of the earnings that the Social Security takes into account for the computation of pension rights. Covered earnings can be regarded as a good proxy for actual earnings, although they are subject to a ceiling and a floor: on the one hand, a minimum contribution must be paid over earnings, independently of the actual amount received; on the other hand, earnings above a given ceiling are not subject to contribution and therefore do not generate further rights.

Moreover, for each employment spell, CSWH 2006 also provides information associated with the job, such as the length and type of contract, worker's Social Security Scheme, the so-called contribution group, as well as limited information about the firm, such as its activity sector and location (province). Available data also include some personal characteristics such as sex, age, place and year of birth. As far as social transfers are concerned, the database contains information about periods and amounts enjoyed for old-age and disability pensions, and survivors' pensions such as, orphanage, widowhood and family help. There is no data on other sources of individual wealth or other sources of income. The CSWH has been matched with information coming from the Census. In the Census' module "Co-inhabitants" there is information about the number of people living with the person in the CSWH dataset, their age and sex, but not their working status.

\footnotetext{
8 A detailed description of the sample can be found in Seguridad Social (2006) and an overview in Argimón and González (2006).
} 


\subsection{The subsample}

The analysis is performed over a subsample that covers all male workers who had contributed to Social Security at least once in their lifetime, had not collected an old age pension before 1997, and were born between 1936 and 1946, so that in 2006 they were between 60 and 70 years old. Moreover, we restricted the sample to those men whose longest contributory relationship with the Social Security took place in the Social Security General Scheme, ${ }^{9}$ which accounts for about $72 \%$ of total social contributions, and who had not claimed disability benefits. We also dropped a limited number of individuals whose available labour and pension history did not seem to be consistent.

Several reasons justify restricting the analysis to the specified subsample. First, the sample only refers to men because women often have quite different labour patterns that can be rather gender specific. In particular, women often experience a greater number of career interruptions than men during their potential working life-due, for instance, to maternity leaves — so that different gender-linked behaviour in labour participation could be expected. Furthermore, women may react differently to economic incentives. In particular, the literature that examines retirement's decisions within households shows that women respond significantly to the employment situation of their husbands, choosing to retire at the same time as their partners Gustman and Steinmeier (2004). Data about socio-demographic characteristics, such as marital status are poorly recorded in the CSWH. The available information on age and gender of people living in the same household, which could be used to proxy civil status, corresponds to the data provided when the administrative records were registered for the first time and moreover, there is no reference whatsoever to the spouse's working status, labour history or Social Security contributions. Hence, it is not possible to consider the joint decision to retire using these data.

Second, given that our aim is to analyze retirement decisions taken by the elderly, we restrict the initial sample to people that were aged from 60 to 70 in 2006 (i.e. those born between 1936 and 1946) and that had already become entitled to a pension benefit, defined in terms of being able to prove at least 15 contributory years. Third, the exclusion of those that received an old-age pension coming from disability is justified as the determinants to claim such kind of pension are most likely linked to health, which is not comparable with the rest of the determinants. Moreover, in this case, the transition to the old-age retirement scheme is deterministic, as disability pensions are transformed into retirement pensions once the beneficiaries turn 65 years old. Finally, to ensure homogeneity in pension rules, the sample is limited to those whose longest recorded labour relation had taken place in the Social Security General Scheme, which is the one that gathers the largest proportion of workers. The sub-sample we use for the analysis comprises 35,853 men, whose distribution by year of birth and retirement age is reflected in Table 1.

The last row in Table 1 reflects the observed hazard rates at each age. We can see that there are clearly two spikes: one at 60 and the next one at 65 , the first allowed and the normal retirement age, respectively.

9 The other Schemes, including the self employed scheme, do not allow, in general, for early retirement. 


\subsection{Variables}

The dependent variable in the model is the length of time until retirement: i.e the time that has elapsed since becoming eligible. The impact of the regulatory change introduced from 2002 is analysed with the introduction of a dummy variable (r2002) to capture its effects. In particular, we also use multiplicative dummy variables to analyse the impact of the new rules on the response to social security incentives.

The explanatory variables that have been included in the specification $\left(\mathrm{X}_{i}\right)$ can be grouped in three main categories: social security regulation, labour characteristics, personal and other variables. A detailed description of these variables can be found in Appendix B. We estimate a Random Effects logit model so as to deal with unobserved heterogeneity.

\subsubsection{Social Security variables}

We build up traditional measures of incentive mechanisms that are standard in this literature. In particular, we use the Replacement Rate $\left(\mathrm{RR}_{t}\right)$, which is the ratio of the expected pension benefits over wages, the Social Security Wealth $\left(\mathrm{SSW}_{t}\right)$, that is, the present discounted value of the future stream of pension benefits, the Accrual Rate $\left(\mathrm{SSA}_{t}\right)$ which measures the discounted change in SSW from postponing retirement 1 year and the Peak Value $\left(\mathrm{PV}_{t}\right)$, that compares this year's social security wealth to the maximum social security wealth that could be attained in the future. They are constructed in real terms under the assumptions that: (i) death is certain beyond a given age, ${ }^{10}$ while accounting for survival probabilities (ii) no changes in social security regulation are expected by individuals, and (iii) it excludes any tax considerations. ${ }^{11}$

Table 2 provides summary statistics for the Social Security variables. It shows that, on the one hand, the average stock of wealth was higher after the 2002 reform than before; on the other, that the incentives linked to it were lower, while RR was higher, implying that the monetary incentives to postpone retirement had decreased.

Both the level of social security wealth and the different incentive variables enter the equation. The level captures wealth effects: the larger the value of wealth, the larger the demand of all goods, including leisure, if leisure is a normal good. The incentive variables capture the substitution effect: the higher the price for leisure, the lower its demand, so that if there is a larger financial incentive to additional years of work, then individuals will retire later.

\subsubsection{Labour characteristics}

Table 2 also contains information related to working status, distinguishing between those observations corresponding to a person working (1) or being unemployed with unemployment benefits $(\mathrm{u})$ or not working at the time of the decision (nw).

\footnotetext{
10 Specifically we assume death is certain beyond 98 .

11 When taxes are taken into consideration to compute the economic incentive variables, the results in Table 2 are slightly stronger. Moreover, the overall conclusions drawn from the estimation results remain similar.
} 
Table 2 Descriptive values of Social Security incentives and working status

\begin{tabular}{|c|c|c|c|c|c|c|c|c|c|}
\hline & \multicolumn{3}{|c|}{ All period considered 1996-2006 } & \multicolumn{3}{|c|}{ Before 2002} & \multicolumn{3}{|c|}{ After 2002} \\
\hline & Median & Mean & SD & Median & Mean & SD & Median & Mean & SD \\
\hline $\mathrm{SSW}_{\mathrm{t}}^{\mathrm{a}}$ & 192.89 & 218.01 & 95.50 & 194.65 & 211.37 & 86.50 & 191.66 & 221.43 & 99.65 \\
\hline $\mathrm{SSA}_{\mathrm{t}}^{\mathrm{a}}$ & 7.77 & 7.83 & 12.12 & 11.00 & 10.86 & 11.53 & 5.87 & 6.26 & 12.12 \\
\hline $\mathrm{PV}_{\mathrm{t}}^{\mathrm{a}}$ & 30.82 & 39.39 & 40.45 & 40.36 & 47.22 & 40.56 & 25.66 & 35.36 & 39.79 \\
\hline $\mathrm{RR}_{\mathrm{t}}^{\mathrm{b}}$ & 56.25 & 66.25 & 34.67 & 49.79 & 56.31 & 26.20 & 60.60 & 71.36 & 37.29 \\
\hline $1_{t-1}^{b}$ & & 62.87 & & & 71.67 & & & 58.33 & \\
\hline $\mathrm{u}_{\mathrm{t}-1}^{\mathrm{b}}$ & & 17.78 & & & 19.18 & & & 17.05 & \\
\hline Other $_{t-1}^{b}$ & & 19.35 & & & 9.15 & & & 24.61 & \\
\hline $\mathrm{N}$ & & 115,532 & & & 40,123 & & & 75,409 & \\
\hline $\mathrm{n}$ & & 35,853 & & & 16,212 & & & 28,259 & \\
\hline
\end{tabular}

Sample of men born between 1936 and 1946, having worked in the General Regimen and with a relation with the Social Security in 2006

$N$ Number of observations, $n$ people

SSW Social Security Wealth: present value of future stream of Social Security benefits that an individual is entitled given her work history and her retirement age. SSA Social Security Accrual: discounted change in SSW from postponing retirement by 1 year $P V$ Peak Value: Difference between SSW today and the maximum SSW from postponing it at some point in time in the future. $R R$ Replacement rate: Is the ratio of the expected pension benefits over wages received before retiring. $l_{\mathrm{t}-1}$ working at $\mathrm{t}_{\mathrm{t}-1} ; \mathrm{i} u_{\mathrm{t}-1}$ unemployed at ${ }_{\mathrm{t}-1} ;$ Other $_{\mathrm{t}-1}$ : neither unemployed nor working at $\mathrm{t}_{\mathrm{t}-1}$

(See Appendix B for a detailed explanation of the variables included in this table)

${ }^{\mathrm{a}}$ In thousands of euros

${ }^{\mathrm{b}}$ In percentage

(The remaining working status corresponds to already retired workers). The proportion of unemployed has increased during the period considered while the ratio workers/non workers has declined in the period after the reform.

Other control variables for labour characteristics is the industry where the individual works, distinguishing between services sector and manufacturing, and some measures of labour mobility or rotation. In particular, we have included two variables as proxies for the degree of job turn-over: the number of different periods of contribution, (that includes both labour and unemployment periods), and their average length in years.

\subsubsection{Personal and other variables}

We also control for age, education and health status and for other social benefits as they may interact with the old age pension. The specification chosen also allows testing whether the individual leaves his current situation during the first year he is entitled to collect a pension benefit. Regional dummy variables and GDP growth are also included to control for the macro environment.

The duration dependence of the hazard rate is captured in two ways. On the one hand, following Bover et al. (2002), instead of imposing a specific functional form for duration, we introduce additive dummy variables for each of the possible discrete values of the duration variable. Durations of more than 6 years (which would 
necessarily imply that the person is at least 66) are treated as censored at 6 , due to the relatively small number of observations under such a circumstance. On the other hand, interaction of certain independent variables with the duration are included to test if the variable effects change with the number of years that a person takes to retire.

\section{Results}

The qualitative impacts of the variables on the hazard are discussed in terms of sign, magnitude and statistical significance of the estimated coefficients, which are reported in detail in Table 6 in Appendix B. Table 6 shows the results obtained under three different specifications that contain two different sets of Social Security incentive variables. So, under model A, we present the estimated coefficients obtained for the basic specification, distinguishing between the Accrual Rate (SSA) and the Peak Value (PV) as the incentive variable. Model B tries to capture the impact of the 2002 reform through the inclusion of dummy variables that test for its relevance and its impact on the response to the social security variables, while model $\mathrm{C}$, also includes dummy variables that capture the effect on the retirement hazard rate of having contributed to the minimum or the maximum amount at each age.

The effect of the Social Security incentive variables on the probability of retiring (and for all variables that are continuous) is measured as the effect of a $10 \%$ change in the variable on the predicted hazard. Table 7 for model A and Table 8 for models $\mathrm{B}$ and $\mathrm{C}$ of Appendix B reflect the quantitative impact of a change in all the variables included in the specification. In particular, these tables also record the impact of qualitative variables, from its change from 0 to 1 , so that the estimated coefficients can be interpreted as the direct effect of having such characteristics on the probability of retiring. A distinction of such effects by age is also reported for model A in Table 7 of Appendix B for illustrative purposes.

\subsection{Economic incentives and regulation}

The results in Table 6 show that all the coefficients of social security variables (SSW, SSA and PV) are statistically significant with the expected sign, while a Wald test of joint significance of the Social Security variables also supports such result. Increases in the total present value of the flow of pensions that a person will receive from the year she retires to the year she dies, i.e. a rise in SSW, increases the hazard. Increases in the difference of this amount derived from postponing the retirement (either one or more years) reduce the hazard, irrespectively of whether SSA or PV used to capture the substitution effects. We include only SSA results since both are similar.

In spite of these effects being statistically significant, they are not very large.

As the figures for Model $\mathrm{C}$ in Table 3 show, on average, a $10 \%$ rise in SSW increases the probability of retiring between 60 and 65 years of age by around 4.6 percentage points. Moreover, these probabilities show a U-shaped form with age (Table 7 ), reaching the highest impact at 65 , so that the closer a worker is to that age, the more responsive to changes in SSW becomes. 
Table $3 \%$ Quantitative effects of Social Security measures on the retirement probability

\begin{tabular}{|c|c|c|c|c|}
\hline \multirow[t]{2}{*}{ Age } & \multirow[t]{2}{*}{ Predicted hazard } & \multicolumn{3}{|c|}{$\% \Delta$ in predicted hazard } \\
\hline & & $10 \% \Delta \mathrm{SSW}$ & $10 \% \Delta \mathrm{SSA}$ & $10 \% \Delta \mathrm{RR}$ \\
\hline \multicolumn{5}{|c|}{ Model C-Period: 2002-2006 (SSA) } \\
\hline 60 & 0.14 & 5.89 & -0.45 & 0.39 \\
\hline 61 & 0.06 & 8.08 & -0.49 & 0.53 \\
\hline 62 & 0.08 & 7.88 & -0.34 & 0.55 \\
\hline 63 & 0.08 & 7.95 & -0.21 & 0.60 \\
\hline 64 & 0.19 & 5.97 & -0.01 & 0.53 \\
\hline 65 & 0.75 & 1.36 & -0.12 & 0.15 \\
\hline Average & 0.160 & 4.60 & -0.13 & 0.36 \\
\hline
\end{tabular}

Quantitative effects are reported as the \% change in the predicted hazard. They are computed as the discrete differences of the logistic function evaluated at a $10 \%$ increase in the variables' values with respect to the logistic function evaluated at the observed variables' values. The effects are estimated for the period beginning in 2002. Results are obtained from the regressions presented in Table 6 corresponding to Model C.

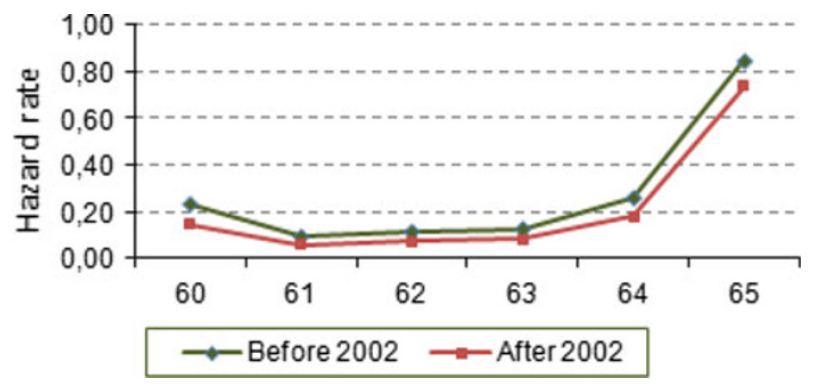

Fig. 1 Predicted hazard rates before and after 2002 by age

As for the incentive variables, we find that increasing by $10 \%$ the difference between what a worker would receive if he retired now and what he would receive if he retired 1 year later (larger SSA) decreases the average probability of retiring between 60 and 65 by an amount ranging between 0.01 and between $0.49 \mathrm{pp}$ if the $10 \%$ increase takes place in PV. The effects on the retirement probability of the SSA and PV incentives are also U-shaped in relation to age (Table 7), so that they are larger at 60 and 65 and lower for the intermediate ages in that age range.

On the other hand, the replacement rate shows the expected positive sign. However, it is not statistically significant.

\subsection{The effects of the 2002 reform}

We observe that the predicted probability of retiring between 60 and 65 is higher before 2002 than after 2002 and this relationship holds for every age in the range from 60 to 65 (Fig. 1).

As already mentioned, in order to test for the role of the 2002 reform on this difference we have estimated our model with a dummy variable that takes value 1 
from 2002 onwards and the interaction of this dummy variable with the Social Security incentives and pension wealth as regressors ${ }^{12}$. The evidence from the signs and t-ratios of these variables (Table 6, models $\mathrm{B}$ and $\mathrm{C}$ ) points out that the reform changed both the pattern of response to the wealth variable, and also, in general the response to the incentive variables. In particular, it reduced its impact on the timing of retirement. This implies that we need a larger value of SSA (or PV) from 2002 onwards to reach the same impact on the hazard. The effects are estimated for the period beginning in 2002. Results are provided in Table 8 . This result could be explained as a consequence of the fact that one of the changes carried out under the reform improved the treatment for those that had more than 30 years of contribution, increasing for them the amount of the pension to be received at each age. The fact that most workers $(64 \%)$ already had at least 30 contributory years (in particular, nearly one third had more than 34 years of contribution), may explain the finding that the reform reduced the incidence of the incentive structure. Additionally, the replacement rate becomes statistically significant for this period, so that a more myopic approach seems to hold. Therefore, the observed reduction in the hazard rate seems to stem from the new regulation, which has reduced its incidence, the reduction in the incentive variables as reflected in Table 2 and also from other factors that are captured by the dummy variable.

\subsection{Contributive floors and ceilings}

Our results show that those workers whose contribution was the regulatory minimum (low topped) have a higher retirement probability at 60 than those who are not topped (Table 8). It could be argued that the minimum contribution offsets the effect of early retirement penalties so that it creates a strong incentive for low income earners to retire, which is especially relevant at 60 . From 61 onwards, being low topped reduces the probability of retirement.

The results also show that high earners (those who have their contributions capped) have a lower probability of retiring both at 64 and 65 (Table 8), in line with the findings in Villagarcía (1995), Blanco (2000) and Labeaga (2008). This finding could result from the fact that, for those workers, financial incentives are not a good proxy for the marginal utility from working. A lower potential wage rate for a elderly workers is likely to be associated with a lower probability of labour force participation as, other things equal, a lower wage rate represents a lower opportunity cost of leisure and a higher replacement rate for government pensions.

\subsection{Duration variables}

Given that individuals enter the sample as soon as they satisfy the requirements to claim a pension, we can interpret the significance of the dummy coefficient for duration one period ( $\mathrm{g} 1$ ) as a test for the relevance of becoming entitled to retirement benefits ${ }^{13}$.

12 See Norton et al. (2004) for a discussion of such test.

13 See Appendix A for a description of these conditions. 


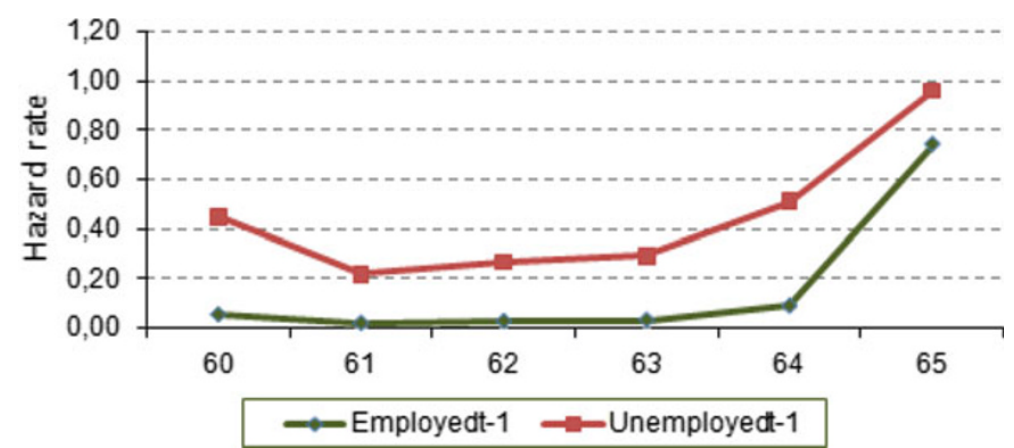

Fig. 2 Predicted hazard rates according to previous working status and age

The coefficient on $\mathrm{g} 1$ is statistically not significant (Table 6), so that becoming eligible by itself is not a relevant ground for retirement. The results show also non-monotonic duration dependence.

In the specification, we also include age dummies to account for differential effects related to this variable. These dummies should capture the effect of growing older "per se", and not through the different coefficients in the calculation of pension rights that are age dependent. The results show that, even when controlling for eligibility criteria and Social security variables, 65 is a prevailing retirement age.

\subsection{Working status}

The labour market status prevailing during the year before the retirement decision seems to be relevant for the retirement hazard. The results show that a person working in a particular year has a lower probability of retiring the following year than a person who was not working. They also show that being unemployed the preceding year increases the probability of retiring. Such findings may only reflect the predominance of special early retirement programs that exist for unemployed old people. ${ }^{14} \mathrm{We}$ also find that the size of these effects varies with age, as can be seen in Fig. 2, showing a u-shaped form.

\subsection{Individual characteristics and other}

The other covariates that we have included in the estimation provide evidence mostly in line with previous empirical findings. ${ }^{15}$ We obtain a negative impact of higher education on the probability of retiring, in agreement with Villagarcía (1995) and

\footnotetext{
14 See García-Pérez and Sánchez-Martín (2008b) for an analysis of the transitions from unemployment for older people.

15 Dummy variables for the region (Autonomous Community) where the worker initially registered are included in the specifications, as a way to capture other differences in the economic environment. Coefficients are not reported but are available under request.
} 
Gutiérrez-Domènech (2006). ${ }^{16}$ Further, the effect of education is reinforced by duration, so that the probability of retiring of a higher educated worker becomes larger the longer the time it has elapsed since becoming eligible.

The results show that job turnover (proxied by the total number of labour relations that a person has had) has a negative impact on the retirement hazard, which fades away as duration increases, a result in line with the findings that workers with a firmspecific training history retire earlier than workers with a general training background (see Montizaan et al. 2007). As for the average length of the contracts held, it plays a significant role in the decision to retire only as time unfolds. Notice, however that, although in general, the longer the contract, the more stable the individual's working life has been, our proxy is not a sophisticated measure of a stable career as the same average may result from quite different job histories.

The finding that those receiving disability benefits the year before retirement show a lower hazard, may reflect the fact that, besides having a poorer health, they will probably be the ones receiving retirement disability pensions when they turn 65 , the only age in which this type of pensions can be awarded, so that they will tend to wait until that age. We also find that those receiving public transfers other than unemployment or disability benefits have a lower retirement probability, which may be a consequence of liquidity constraints.

Our results show that, during the period analyzed, the propensity to retire is procyclical, so that the hazard retirement rate is higher during expansions, in line with the results in Montizaan et al. (2007) for the US, but at odds with the evidence for Spain gathered in Muñoz (1995).

Finally, in contrast with other works where the sector of activity is found to be playing a significant role (Conde-Ruiz and Galasso 2004; Blanco 2000; Villagarcía 1995; Muñoz 1995), we cannot find evidence of differences in retirement behaviour between the service and the industrial sector.

Additionally, to check whether there is any bias resulting from the fact the estimation includes individuals whose contributions are capped (and therefore not equal to their wage), we perform an additional estimation exercise, where only those observations that are not upper or lower capped are considered. According to our results the effect of economic incentives goes in the same direction as when considering all observations. Increases in the total present value of the flow of pensions that a person will receive from the year she retires to the year she dies (increases in SSW) increases the hazard while an increase in the difference of this amount from postponing retirement, SSA, decreases the hazard. Thus, the results remain similar. Moreover, the effect of net economic incentives is slightly stronger than when no tax information is considered, but the overall conclusions drawn in the main text remain similar.

16 Muñoz (1995), on the other hand, finds evidence that the education has a quadratic effect, so that those individuals with little or with a lot of studies retire later than those with an intermediate level of education. 


\subsection{Comparative statics. Alternative regulatory schemes}

Finally, we have performed a few counterfactual policy analysis exercises with the aim of shedding light on how the estimated retirement probabilities respond to small changes in the economic incentive mechanisms underlying the Spanish public pension system. The reason for considering only small changes of the baseline rules is to minimize the Lucas' critique, and also to check whether these small changes would have enough sizeable effects on retirement or more drastic changes would be needed. The analysis in this section should also be interpreted as being only valid during a short period of time, within which individuals would not change their expectations. Therefore, the results in this section should only be considered as an exercise that provides a quantification of what would have happened if alternative retirement reforms were proposed, given the observed behavior of individuals after the pension reform in 2002.

Specifically, we have computed the pension wealth that a person would receive under 3 alternative regulatory schemes implying very small changes over the retirement rules established in the 2002 pension regulatory framework. Recall that under this framework, at least 15 years of contribution were required. With only these minimum contributory years, the pension would reach $50 \%$ of the proxy of gross average lifetime earnings (regulatory base), increasing up to $100 \%$ when 35 years of contribution were reached. We have computed the SSW and the incentive measures that result from the assumed alternative settings for each individual in the sample to obtain counterfactual predicted retirement probabilities. These are compared with the ones predicted from our estimates, which act as a benchmark. The new probabilities are obtained using the specification in column 5 of Table 6. In particular, we compute the changes in relation to the population that in the sample are subject to the rules prevailing in 2002. Each of the three alternative regulatory schemes tries to change only one item in the pension rules.

The first scenario (setting A) would consist of an overall reduction in the amount of the pension received at all ages. It caps the pension at $96 \%$ of the regulatory base, not allowing individuals to get the $100 \%$ of it at any retirement age. Under this scenario, with 15 contributory years, the pension amount is only $48 \%$ of the regulatory base. With 35 or more years of contribution the pension would amount to $96 \%$ of the regulatory base. ${ }^{17}$

The second scenario (setting B) affects mostly the incentive structure as it requires more years of contribution to claim a pension (18 years instead of 15 ), so that the ladder becomes steeper. With 35 years of contributions, the worker receives $100 \%$ of the regulatory base. Moreover, at the age of 66, if the person has more than 35 contributory years, the pension is increased by $3 \% .{ }^{18}$ It must be taken into account

\footnotetext{
17 Up to 25 years of contribution, there would be a 3 pp increase for each additional contributory year, and from 26 , the increase would be $2 \%$ per year up to $96 \%$ at 35 or more years of contribution.

18 There is a 3 pp increase for each additional contributory year up to 25 years. Beyond 25 , the increase is $3.22 \%$.
} 
Table 4 Effects of alternative settings on retirement between ages 60 and 65

\begin{tabular}{llllr}
\hline & Benchmark & Setting A & Setting B & Setting C \\
\hline Predicted retirement probability $^{\mathrm{a}}$ & 80.706 & 80.144 & 79.743 & 80.537 \\
Predicted retirement age $_{\text {Change in number of retired people }}^{\mathrm{a}}$ & 63.021 & 63.033 & 63.027 & 63.019 \\
By age & - & -1.46 & -1.64 & -0.09 \\
60 & - & -1.81 & -1.72 & 0.00 \\
61 & - & -2.42 & -2.18 & 0.00 \\
62 & - & -2.41 & -2.17 & 0.00 \\
63 & - & -2.50 & -2.43 & 0.00 \\
64 & - & -1.91 & -1.99 & 0.00 \\
65 & - & -0.52 & -1.09 & -0.24 \\
\hline
\end{tabular}

The effects are estimated for the period beginning in 2002

Setting A: Capping the pension to $96 \%$ of the Regulatory Base at 35 years of contribution and to $48 \%$ at 15 years of contribution

Setting B: 18 years of contribution to claim a pension. Retiring after 65 implies $3 \%$ increase Setting C: Retiring after 65 implies $2 \%$ increase and $3 \%$ if 40 years of contribution

${ }^{a}$ In percentage

that only $2.6 \%$ of people at 60 have a labour history shorter than 18 years and longer than 15 years, so that the impact on this end of the distribution would be rather small.

The third scenario (setting $\mathrm{C}$ ) proposes changes in the short-term incentives to stay beyond 65 , introducing higher retirement benefits for each additional year beyond that age. It reproduces part of the changes introduced by the "Acuerdo sobre Medidas en Materia de Seguridad Social", of 13 July 2006, which were implemented 2 years later. In particular, at 66 with at least 35 years of contribution, a $2 \%$ increase in the pension is added, raising it to $3 \%$ for those individuals with at least 40 years of contribution.

Table 4 shows the computed counterfactual predicted retirement probabilities for these three scenarios, the average predicted retirement age over the age interval 60-65 and the changes in the number of retirees in the same interval and its disaggregation by ages. All the changes analysed result in an extremely small increase on the average retirement age and a reduction in the number of people who retire between 60 and 65 which ranges from $0.09 \%$ under setting $\mathrm{C}$ to $1.64 \%$ under setting $\mathrm{B}$.

Under the first two scenarios, retirement rates at all ages are affected by the proposed changes and the effects are increasing with age up to 63, when the largest impact is recorded. Retirement age is computed as a weighted average. Weights at each age are computed using predicted probability of retirement under each alternative setting. The smallest effect is at 65 , probably reflecting that this age is regarded as normal retirement age.

Under setting $\mathrm{C}$, there is a very small impact on the probability of retiring between 60 and 64 which in fact is nil under the specification using SSA analised (last column of Table 4). Since PV considers information about the entire time horizon, individuals take into account earlier in their lives changes that will affect them after 65, in contrast with what happens when predictions are derived from the specification with SSA, so that the estimated effect (not shown) is larger. Despite these differences, predicted retirement age is similar under both specifications. 


\section{Conclusions}

There is some agreement that generous early retirement provisions in the Social Security System account for a large proportion of the drop in the labour force participation of elderly workers that had been observed in Spain during the nineties. This paper aims at quantifying the impact of these provisions and in particular, of the 2002 reform.

The evidence gathered shows that, in general, the economic incentives stemming from Social Security regulations on old age pensions in Spain have the expected effect on retirement. The present value of the future flow of pensions has a positive impact on the probability of retiring, with larger pensions shortening the number of years between becoming eligible for retirement and actually claiming the retirement pension. Therefore, all measures taken to reduce the present value of such flow at early ages may have the desired effect of reducing early retirement. Moreover, it seems that the built-in incentives in the system to discourage early retirement have a non negligible effect on old-age retirement, so that they are effective in retaining people in the labour market. The higher flow of pensions that workers receive for staying at work one additional year compensate for both the loss of leisure that they experience for the additional year that they keep contributing and the wage they receive at work. The quantitative size of such effect is statistically significant. Moreover, small variations in the incentives measures have a sizeable effect on early retirement. For the period beginning in 2002, a $10 \%$ increase in SSW (SSA, PV, replacement) results in a $4.6 \%(-0.4 \%,-0.2 \%$ and $0.4 \%)$ increase in the hazard according to estimates in Model C (see Table 3). Therefore, from a policy perspective, regulatory changes that could reinforce such effects are most welcome.

It has also been found that the new framework implemented since 2002 has reduced the probability of retiring at each age, in spite of the fact that the built-in incentives have reduced their incidence on retirement decisions, because of the decline in such incentives, as shown in Table 5. Moreover, there is evidence pointing out to a higher incidence of short term incentives such as the replacement rate on workers' decisions. The changes in the regulation that have taken place may explain such results. In particular, the fact that one of the changes carried out under the reform improved the treatment for those that had more than 30 years of contribution (64\% of the workers), may explain the finding that the reform reduced the incidence of the incentive structure.

Any new change in the incentive structure of pensions should take into account the fact that the new generations have longer work histories when becoming eligible than former ones. The counterfactual results show that a small change in the incentive structure has a small impact on the number of people retiring. It seems that to increase the number of people staying beyond 65 requires more than a tiny push. It is therefore necessary to combine economic incentives with other institutional constraints in order to effectively increase the retirement age.

There is an urgent need to address the consequences of an ageing population on the Social Security accounts. Minor changes in the rules that define the amount received at each age in relation to the years effectively contributed may have a positive impact on the pension accounts, through its impact on the probability to retire at each age. Yet, as the evidence is this paper shows, this effect may be rather limited. Prospective 
amendments in retirement rules should be oriented to link the possibility of retiring and the benefit rights not only to contribution efforts but also to life expectancy.

Open Access This article is distributed under the terms of the Creative Commons Attribution License which permits any use, distribution, and reproduction in any medium, provided the original author(s) and the source are credited.

\section{Appendix A: Legislation}

\section{A.1 The institutional framework and the changes in 2002}

Social Security regulation during the period covered by the sample selected in this paper experienced two main changes in relation to the framework established in 1985: the reforms introduced in 1997 and in 2002.

Up to 1997 only 8 contributory years were required to be entitled to a retirement pension. The change introduced in 1997 increased such minimum to 15, with the additional requirement that two of them had to have taken place during the last 15 years. Full implementation was expected for 2002, with a progressive timetable set up to that year.

The normal retirement age in Spain, that is the age when a person becomes eligible for the full pension benefit, is 65 . Up to 2002, early retirement was possible from the age of 60 only for those who had contributed to the labour mutual funds system (former Social Security System) before January 1, 1967. An early retirement penalty defined by a reduction coefficient, which is detailed below, was in place. The 2002 reform extended early retirement to all workers, from the age of 61, if they complied with certain conditions that are detailed below. On the other hand, the reform also set incentives to promote retirement beyond the age of 65 . In particular, the 2002 reform established:

- Access to early retirement since the age of 61 , if : a) the worker's contributory years were at least 30 ; b) the termination of his last employment had been involuntary and c) he had spent at least 6 months as involuntarily unemployed and registered as job seeker in the Public Employment Service Offices, during the period immediately preceding the pension claim.

- Stronger linkages between the contributive effort exerted by workers and the pension received. Workers who wanted to retire between 64 and 61 years of age were charged with a penalty that decreased with both age and total years of contribution.

- Premium to postponing retirement. Each full year of employment beyond statutory retirement age (65), implied a $2 \%$ increase in the regulatory base to compute retirement benefits, only applicable to those workers with at least 35 years of contributions.

- Retiring at the age of 64 was also possible without age penalty. Moreover, it did not require a previous period of unemployment, but just the minimum 15 contributory years. However, in this case, the firm had to hire another worker for a minimum period of a year with a substitution contract to replace the retiring worker.

- It became possible to receive a partial pension from the age of 60 whilst continuing to work part-time. Workers could partially retire if the firm replaced the retiree with another worker (relief contract) to compensate for the retiree's reduction in 
work-time. The amount of the pension was then conditioned by the reduction in working hours (between 25 and $85 \%$ ).

The database does not provide information about contributions dating from before the seventies, while all men born between 1936 and 1946 could potentially have been working by 1967, as the youngest would have started working at the age of 21. Therefore, the assumption in the empirical part is that all people in the sample contributed to the labour mutual funds system, so that they only need 15 years of contribution to be entitled to retire. In fact, in the sample $34 \%$ of those we observe retiring, do so at 60 and $40 \%$ do so with less than 30 registered years of contribution.

The last two points in the reform are not taken into account in the analysis as they require information from the demand side, which we do not have.

\section{A.2 The pension amount}

The amount of the old age pension is defined by the interaction of different elements. On the one hand, the Regulatory Base (Base reguladora, BR) that defines the amount of the pension and it is directly related to the contribution bases received. ${ }^{19}$ The minimum and maximum contributory periods to be considered in its calculation and the inflation correction mechanism to obtain its present value are regulatory defined. Moreover, there are minimum and maximum pensions that are yearly defined and its amount depends on marital status and number of economically dependent people who depend on the person receiving the benefit. A person retiring between 1985 and 1996 had a regulatory base defined as:

$$
B R_{t}=\frac{1}{112}\left(\sum_{j=1}^{24} w_{t-j}+\sum_{j=25}^{96} w_{t-j} \frac{I_{t-25}}{I_{t-j}}\right)
$$

where $\mathrm{w}_{\mathrm{t}-\mathrm{j}}$ are covered earnings for the $\mathrm{jth}$ month before retiring at $\mathrm{t}$ and $\mathrm{I}_{\mathrm{t}-\mathrm{j}}$ is the price index for the jth month before retirement, and where only 8 years were taken into account.

Since 2002, the regulatory base is defined taking into account the last 15 years:

$$
B R_{t}=\frac{1}{210}\left(\sum_{j=1}^{24} w_{t-j}+\sum_{j=25}^{180} w_{t-j} \frac{I_{t-25}}{I_{t-j}}\right)
$$

A transitory period was set from 1997 to 2002 such that each year, one additional year was included in the up-rated part of the weighted average and, therefore the 15 years were finally accounted for the definition of the regulatory base in $2002^{20}$.

\footnotetext{
19 Different caps have been in place for different types of workers depending on their group of contribution (grupo de cotización) associated with type of job and education level.

20 As social contributions are paid 14 months a year, the effective number of years taken into account to compute the regulatory base was 6.8 up to 1997 and 12.9 since then.
} 
The relation between the first monthly pension received at time $t\left(B_{t}\right)$ and the regulatory base $\left(B R_{t}\right)$ calculated at $t$ can be expressed as $B_{t}=\alpha_{n t}^{T} \cdot B R_{t}$ where $\alpha_{n t}^{T}=\alpha_{n t}^{y} \alpha_{n t}^{a}$, so that $\alpha_{n t}^{y}$ depends only on contributory years $(n)$, and $\alpha_{n t}^{a}$ depends on the age of retirement.

If retirement age is equal or larger than 65 then, and up to 1997, $\alpha_{n t}^{a}=1$ and $\alpha_{n t}^{T}$ is expressed as:

$$
\alpha_{n t}^{T}= \begin{cases}0, & \text { if } n<15 \\ 0.6+0.02(n-15), & \text { if } 15 \leq n<35 \\ 1, & \text { if } 35 \leq n\end{cases}
$$

The reform introduced in 1997 modified the number of years to define the contributory base and the substitution rate $\left(\alpha_{n}^{T}\right)$ if age of retirement was equal or larger than 65 , so that:

$$
\alpha_{n t}^{T}= \begin{cases}0, & \text { if } n<15 \\ 0 \cdot 5+0.03(n-15), & \text { if } 15 \leq n<25 \\ 0 \cdot 8+0.02(n-25), & \text { if } 25 \leq n<35 \\ 1, & \text { if } 35 \leq n\end{cases}
$$

That new scheme thus implied a more progressive approach to full benefits. For early retirement, regulation also sets a penalization system linked to age. Mutualistas that retire early were subject to a reduction coefficient equivalent to $8 \%$ for each year in advance of 65 that he/she retires, so that $\alpha_{t}^{a}=1-0.08(65-r)$ where $r>=60$. The 1997 reform reduced the reduction coefficient to $7 \%$ for those with more than 40 contributory years, when claiming the pension. This coefficient should be jointly applied with the one corresponding to contributory years.

The 2002 reform changed the penalization mechanism, so as to make the age coefficient $\left(\alpha_{t}^{a}\right)$ more linked to the number of contributed years, so that:

$$
\begin{gathered}
\alpha_{n t}^{a}= \begin{cases}0 & \text { if } r<61 \\
a+k(r-60), & \text { if } 61 \leq r<65 \\
1, & \text { if } r \geq 65\end{cases} \\
\text { where } \begin{cases}a=0.6 ; k=0.08 & \text { if } n<31 \\
a=0.625 ; k=0.075 & \text { if } 31 \leq n \leq 34 \\
a=0.65 ; k=0.07 & \text { if } 35 \leq n \leq 37 \\
a=0.675 ; k=0.065 & \text { if } 38 \leq n \leq 39 \\
a=0.7 ; k=0.06 & \text { if } n \geq 40\end{cases}
\end{gathered}
$$

where $\mathrm{r}$ is retirement age.

Moreover, the 2002 Amendment introduced a premium for late retirement, so that the pension was increased by $2 \%$ per additional year of work beyond 65 , if the worker had more than 35 years of contribution.

$$
\alpha_{n}^{T}=1+0.02(r-65) \text { if } r>65 \text { and } n \geq 35
$$




\section{Appendix B: Data}

This appendix contains the definition of the variables included in the different specifications. As already mentioned in the text, the data source is the Continous Sample of Working Histories (CSWH) 2006, "Muestra Continua de Vidas Laborales" in Spanish.

The main descriptive statistics for each variable are presented in Table 5.

\section{B.1 Economic incentive variables}

To calculate the Social Security benefits to which individuals in the sample are entitled, we make use of the Social Security covered earnings histories of individual in the CSWH 2006.

$\mathbf{S S W}_{\text {it }}$ : Value of Social Security Wealth of individual i at time t, at 2006 prices:

$$
S S W(r)_{i t}=\sum_{s=t}^{s=L}\left[B_{i}(s, r)\left[p(s \mid t)_{i} /\left(1+\rho_{i}\right)^{s-t}\right]\right]
$$

indicates Social Security Wealth at time $\mathrm{t}$ (at age $\mathrm{t}$ ) if retiring at age $\mathrm{r}$; $\mathrm{L}$ is the maximum life length, $B_{i}(s, r)$ is the pension benefit in period $\mathrm{s}$ (at age $\mathrm{s}$ ) if retiring at $\mathrm{r}, \mathrm{p}(\mathrm{s} \mid \mathrm{r})$ is the conditional probability of an individual at time $t$ to be alive at time $s$ where $s>r$, $\rho_{i}$ is the individual discount rate.

To calculate the pension, we make use of data on covered earnings and from it we build the Regulatory Base which is computed, following the regulation, as a moving average of the contribution bases of the 15 years immediately before retirement. The minimum base that has been used to complete job careers has been the one corresponding to contributory group 5, senior administrative ("oficial administrativo"), the group with the largest volume of population. On the other hand, the maximum base has been taken to be the one corresponding to group 1, Engineers and Graduates ("Ingenieros $y$ Licenciados"), the group with the highest base for all the years. The maximum life length (T) is assumed to be 98 years; $\rho_{i}$, the individual discount rate is assumed to be fixed at $3 \%, \mathrm{p}(\mathrm{s} \mid \mathrm{r})$, the conditional probability of an individual aged $\mathrm{r}$ to be alive at age $s$, has been taken from the National Statistics Institute (INE) demographic projections (scenario 2), based upon 2001 Census data. Pensions and covered earnings are assumed to increase $2 \%$ yearly from 2006, while for previous years we use their actual rate of change. Upper and lower limits on the pension benefits are applied to compute retirment pension (the minimum one corresponds to a worker with a dependent spouse). Not considering heterogeneity on survival probability among individuals with different income levels, as well as on discount rates, could be understood as a limitation on the assumptions behind the incentive variables used in the estimation. However, heterogeneity in official estimates of life expectancy by socioeconomic level are not available in Spain, and though it would be possible to estimate them, presumably they would not differ too much, since the country is not characterized by such remarkable levels of wealth inequality. Maybe additional research would be needed to analyze the impact of considering different discount rates, also linked to income level. 
Table 5 Descriptive values

\begin{tabular}{|c|c|c|c|c|c|c|c|c|c|}
\hline & \multicolumn{3}{|c|}{$\begin{array}{l}\text { All period considered } \\
\text { 1996-2006 }\end{array}$} & \multicolumn{3}{|c|}{ Before 2002} & \multicolumn{3}{|c|}{ After 2002} \\
\hline & Median & Mean & SD & Median & Mean & SD & Median & Mean & SD \\
\hline $\mathrm{SSW}_{\mathrm{t}}^{\mathrm{a}}$ & 199.30 & 222.50 & 96.83 & 195.83 & 211.84 & 87.02 & 201.35 & 228.17 & 101.21 \\
\hline $\mathrm{SSA}_{\mathrm{t}}^{\mathrm{a}}$ & 6.89 & 6.73 & 12.95 & 10.12 & 9.79 & 12.20 & 4.97 & 5.09 & 13.04 \\
\hline$P V_{t}^{a}$ & 12.65 & 18.84 & 26.73 & 21.68 & 26.77 & 28.03 & 8.32 & 14.63 & 25.01 \\
\hline $\mathrm{RR}_{\mathrm{t}}^{\mathrm{b}}$ & 57.61 & 67.36 & 35.50 & 50.77 & 57.61 & 26.56 & 61.93 & 72.55 & 38.45 \\
\hline $\mathrm{l}_{\mathrm{t}-1}^{\mathrm{b}}$ & & 57.49 & & & 62.67 & & & 54.74 & \\
\hline$u_{t-1}^{b}$ & & 24.28 & & & 27.54 & & & 22.55 & \\
\hline numrel & & 10.770 & 25.866 & & 9.547 & 19.763 & & 11.420 & 28.565 \\
\hline meanlenght ${ }^{\mathrm{c}}$ & & 7.237 & 7.243 & & 7.763 & 7.436 & & 6.957 & 7.122 \\
\hline time since eligible ${ }^{c}$ & & 2.677 & 1.565 & & 2.275 & 1.390 & & 2.892 & 1.609 \\
\hline univ & & 0.106 & 0.307 & & 0.101 & 0.302 & & 0.108 & 0.310 \\
\hline serv & & 0.364 & 0.481 & & 0.356 & 0.479 & & 0.367 & 0.482 \\
\hline disab & & 0.126 & 0.332 & & 0.024 & 0.152 & & 0.181 & 0.385 \\
\hline otherben & & 0.134 & 0.341 & & 0.030 & 0.172 & & 0.190 & 0.392 \\
\hline low60 & & 0.086 & 0.281 & & 0.101 & 0.302 & & 0.078 & 0.268 \\
\hline low61 & & 0.047 & 0.211 & & 0.034 & 0.181 & & 0.053 & 0.224 \\
\hline low62 & & 0.029 & 0.168 & & 0.015 & 0.123 & & 0.036 & 0.187 \\
\hline low63 & & 0.018 & 0.134 & & 0.008 & 0.091 & & 0.024 & 0.152 \\
\hline low64 & & 0.011 & 0.104 & & 0.005 & 0.067 & & 0.014 & 0.120 \\
\hline low65 & & 0.008 & 0.086 & & 0.003 & 0.053 & & 0.010 & 0.100 \\
\hline top64 & & 0.001 & 0.037 & & 0.001 & 0.025 & & 0.002 & 0.042 \\
\hline top65 & & 0.003 & 0.058 & & 0.001 & 0.034 & & 0.005 & 0.067 \\
\hline age61 & & 0.219 & 0.413 & & 0.236 & 0.425 & & 0.209 & 0.407 \\
\hline age 62 & & 0.175 & 0.380 & & 0.158 & 0.365 & & 0.184 & 0.387 \\
\hline age63 & & 0.135 & 0.342 & & 0.110 & 0.313 & & 0.148 & 0.355 \\
\hline age64 & & 0.100 & 0.300 & & 0.068 & 0.252 & & 0.118 & 0.322 \\
\hline age 65 & & 0.065 & 0.246 & & 0.027 & 0.162 & & 0.085 & 0.278 \\
\hline cycle $^{\mathrm{d}}$ & & 3.667 & 0.679 & & 4.262 & 0.688 & & 3.350 & 0.406 \\
\hline r2002 & & 0.653 & 0.476 & & 0.000 & 0.000 & & 1.000 & 0.000 \\
\hline
\end{tabular}

Sample of men born between 1936 and 1946, having worked in the General Scheme

${ }^{a}$ In thousands of euros

${ }^{\mathrm{b}}$ In percentage

${ }^{\mathrm{c}}$ In years

${ }^{d}$ Percentage variation of GDP

Assumed discount rates, and minimum and maximum pension, are homogeneous to ensure simplicity in the analysis.

In order to calculate the different incentive measures, we need to project SSW for the future. Two different situations arise, depending on the age of the individual and whether or not he has retired. For those that are not 66 before 2006, we need to project their pension and their SSW beyond this year. To do so, we assume that their salary 
and, therefore, their contributory base will be increasing at a $2 \%$ rate every year. For those that have retired before 2006, we project their salaries for the years before 2006 assuming that they keep the purchasing power of their last observed salary (or the following one), so that the contributory base increases by the same amount as the December over December CPI $\left(\Pi_{t}\right)$

$\mathbf{S S A}_{\text {it }}$ : The accrual rate,

$$
S S A(r)_{i t}=1 /\left(1+\rho_{i}\right) S S W(r+1)_{i t}-S S W(r)_{i t}
$$

and we let

$$
S S W(r+1)_{i t}=\frac{S S W(r+1)_{i t+1}}{\left(1+\Pi_{t}\right)}
$$

A limitation of this index is that it does not take into account the comparison that the individual can make between pension benefits and the level of his/her income. It could be argued that the leisure preference is such that wages can fully compensate for the forgone leisure enjoyment from postponing retirement.

$\mathbf{P V}_{\text {it }}$ : Peak Value computed between the ages of 60 and 65 is defined as,

$$
\begin{aligned}
P V_{i}(r) & =\max \left(S S W(r, r+1)_{i}, S S W(r, r+2) r_{i}, S S W(r, r+3)_{i}, \ldots, S S W(r, 66)_{i}\right) \\
& =S S A_{i}, \text { otherwise }
\end{aligned}
$$

where

$$
S S W(r, r+j)=S S W(r+j) /(1+\rho)^{j}-S S W(r)
$$

We follow Coile and Gruber (2000) and restrict the peak value to be equal to the accrual rate, if the individual works beyond the highest value for his social security wealth.

$\mathbf{R R}_{i t}$ : Replacement rate, $R R_{i}(r)$ is the ratio of the expected pension benefits $B_{i}(r)$ at time t over wages $w_{i}(r)$ received at time $\mathrm{t}-1$ for individual $i$ at age $r$, if the person retires at age $r$.

$R R_{i}(r)=E_{r}\left(B_{i}(r) / w_{i}(r)\right)$ where $\mathrm{E}$ is the expectation operator.

\section{B.2. Other variables}

$\mathbf{d i s a}_{\mathrm{it}-1}$ : Dummy variable that takes value 1 at age $t$ if the person was receiving any disability benefit while he was a year younger (at age $t-1$ ) and zero, otherwise. univ $_{\mathrm{i}}$ : Dummy variable that takes value 1 if the contributory group ("grupo de cotización") of the longest contributory relationship with the Social Security system is the one with the highest academic qualifications (group 1: "Engineers and Graduates"), and zero, otherwise. 
numrel $_{i}$ : Number of contributory labour relations that have been recorded by the Social Security before becoming entitled to an old age pension and that include those involving the perception of unemployment benefits.

\section{Regional Government (Comunidad Autónoma) where the worker initially regis-}

tered: Group of 19 dummy variables, each one corresponding to a CA, plus one for Ceuta and one for Melilla, that records the initial worker's registration.

$\operatorname{serv}_{\mathrm{i}}$. Dummy variable that takes value 1 if the longest job a person has held has taken place in the following CNAE sector classifications: Trade (50 to 52), Restoration (Hostelería) (55), Transport (60 to 64), other services, including education y health (65 to 67,70 to $74,80,85$ and 90 )

$\mathbf{u}_{\mathrm{it}-1}$. Dummy variable that takes value 1 at age $\mathrm{t}$ if the person was receiving unemployment benefits, either as a subsidy or a contributory transfer, while he was a year younger (at age $t-1$ ), and zero, otherwise. (That is, people whose relationship with Social Security is coded as a TRL 751-756 in the administrative files).

$\mathbf{l}_{\mathrm{it}-1}$. Dummy variable that takes value 1 at age $\mathrm{t}$ if the person was working and contributing to Social Security while he was a year younger (at age $t-1$ ), and value zero, otherwise.

g_ $\mathbf{k}_{\mathrm{it}}$ : Dummy variables that take value 1 if the person is at age $\mathrm{t}$ in the $\mathrm{k}-\mathrm{th}$ period decision and value zero otherwise, where $\mathrm{k}=[1,6]$. That is, $\mathrm{g}$ - $\mathrm{k}$ takes value 1 if the value of the length of the spell from the year the person becomes entitled to a retirement pension is $\mathbf{k}$.

age_k $\mathbf{k}_{\text {it }}$ : Dummy variables that take value 1 if the person is $k$ years old at time $t$ and zero otherwise, where $\mathrm{k}=[60,65]$.

cycle $_{\mathrm{t}}$ : Spanish GDP real growth rate (for years 1997 to 2006)

r2002:Dummy variable that takes value 1 if the year of the observation is greater than 2001.

otherben $_{\text {it }-1}$ : Dummy variable that takes value 1 at time $t$ if the person was receiving any Social Security benefit other than disability, old age or unemployment while he was a year younger (at age $\mathrm{t}-1$ ) and zero, otherwise.

mlength $_{\mathrm{i}}$ :Average number of years for the spells that the individual $\mathrm{i}$ has had before becoming entitled to a pension.

tr: a linear time trend

low60 $0_{\text {it }}$ : Dummy variable that takes value 1 if the person's contribution was the regulatory minimum at 60

low6 $1_{\text {it }}$ : Dummy variable that takes value 1 if the person's contribution was the regulatory minimum at 61

top64 $4_{\text {it }}$ : Dummy variable that takes value 1 if the person's contribution was the regulatory maximum at 64

low65 $5_{\text {it }}$ : Dummy variable that takes value 1 if the person's contribution was the regulatory maximum at 65 .

See Tables 5, 6, 7, 8 . 


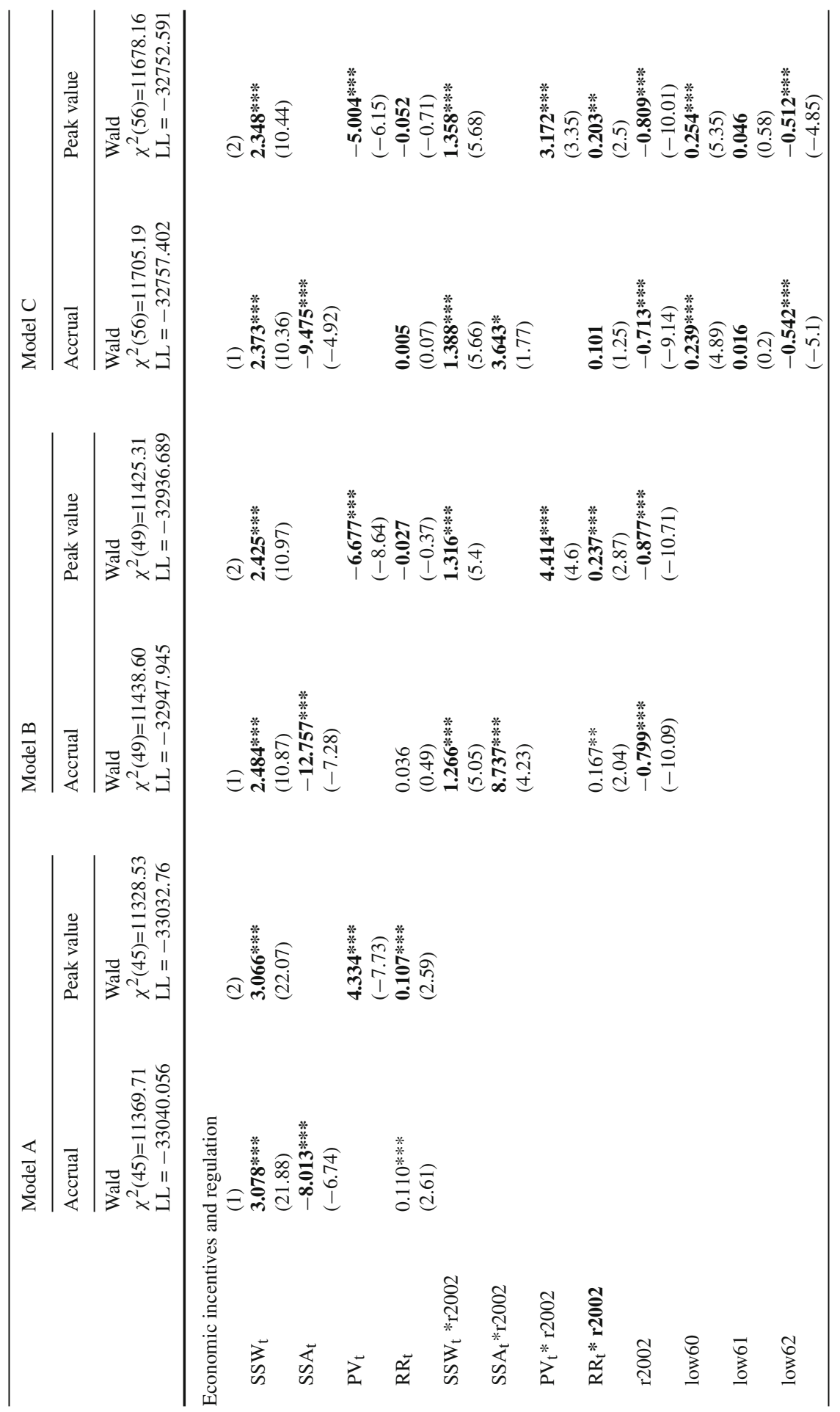




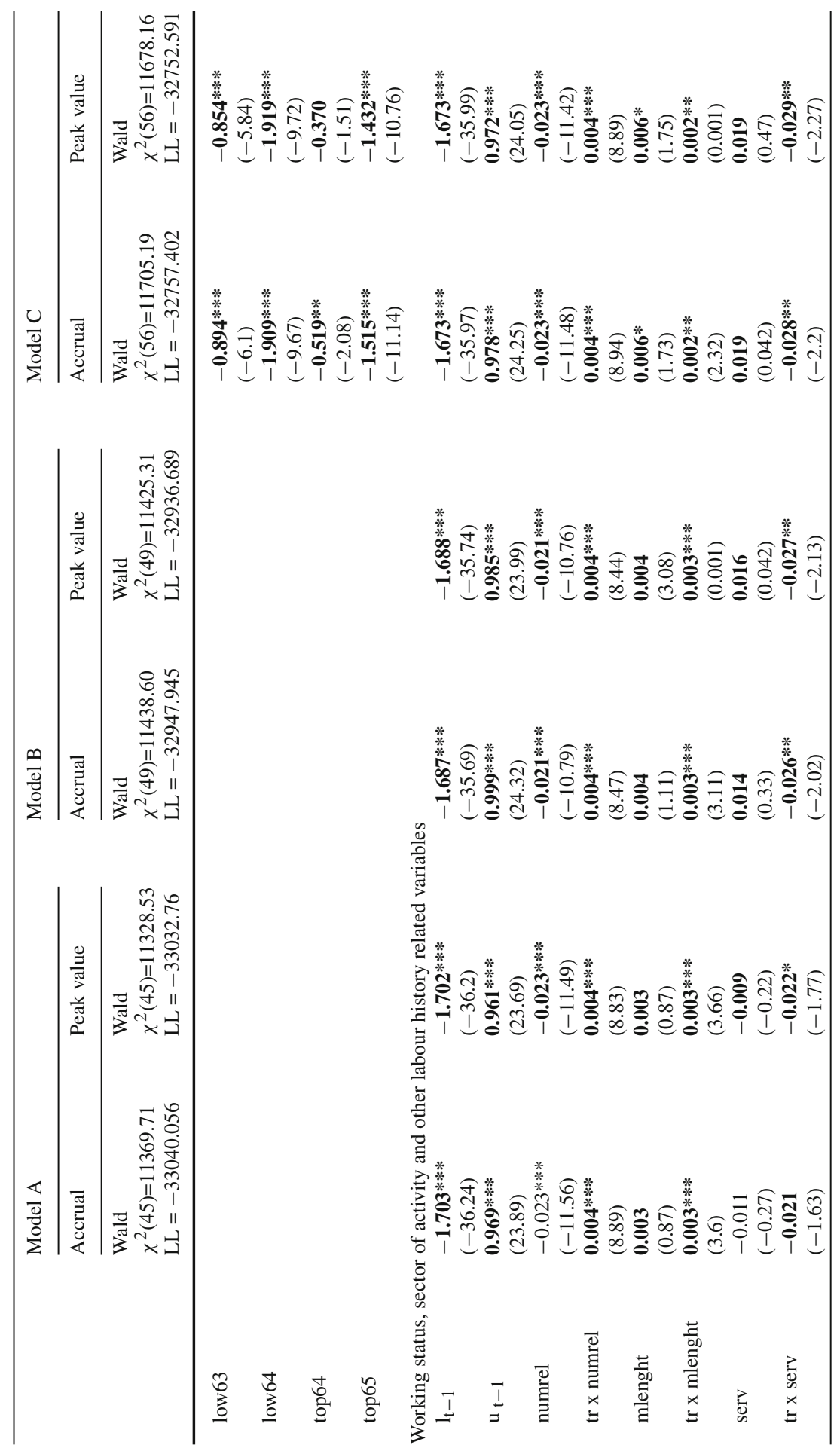




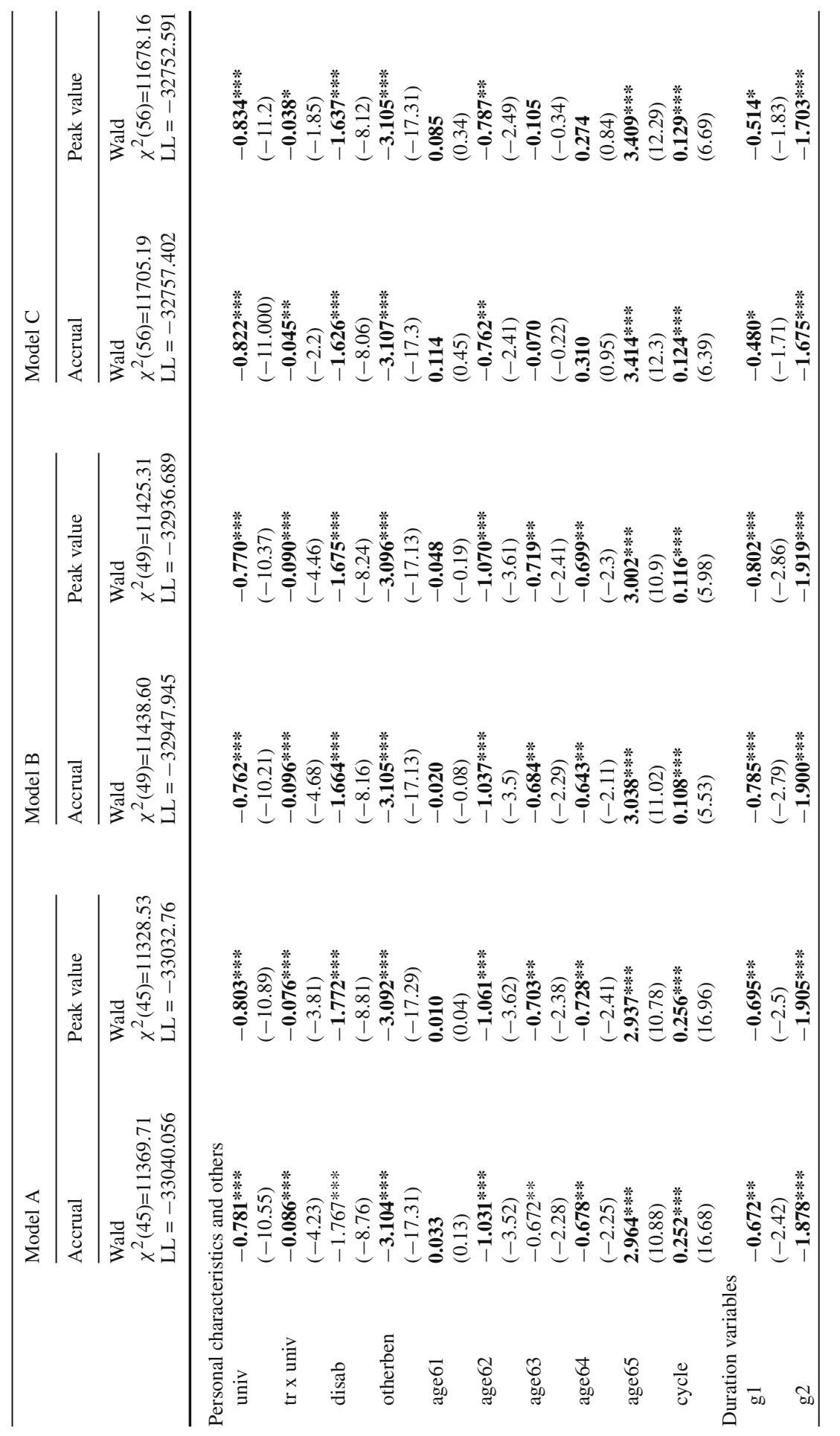




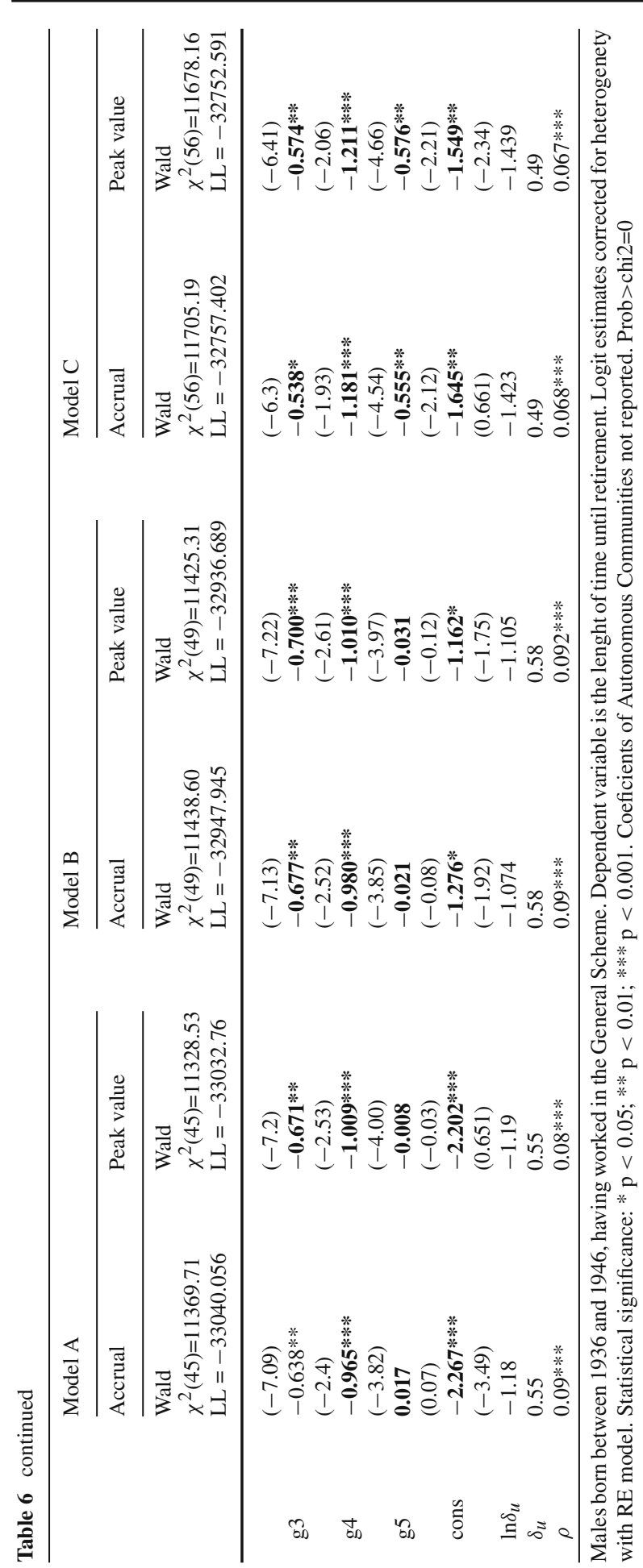




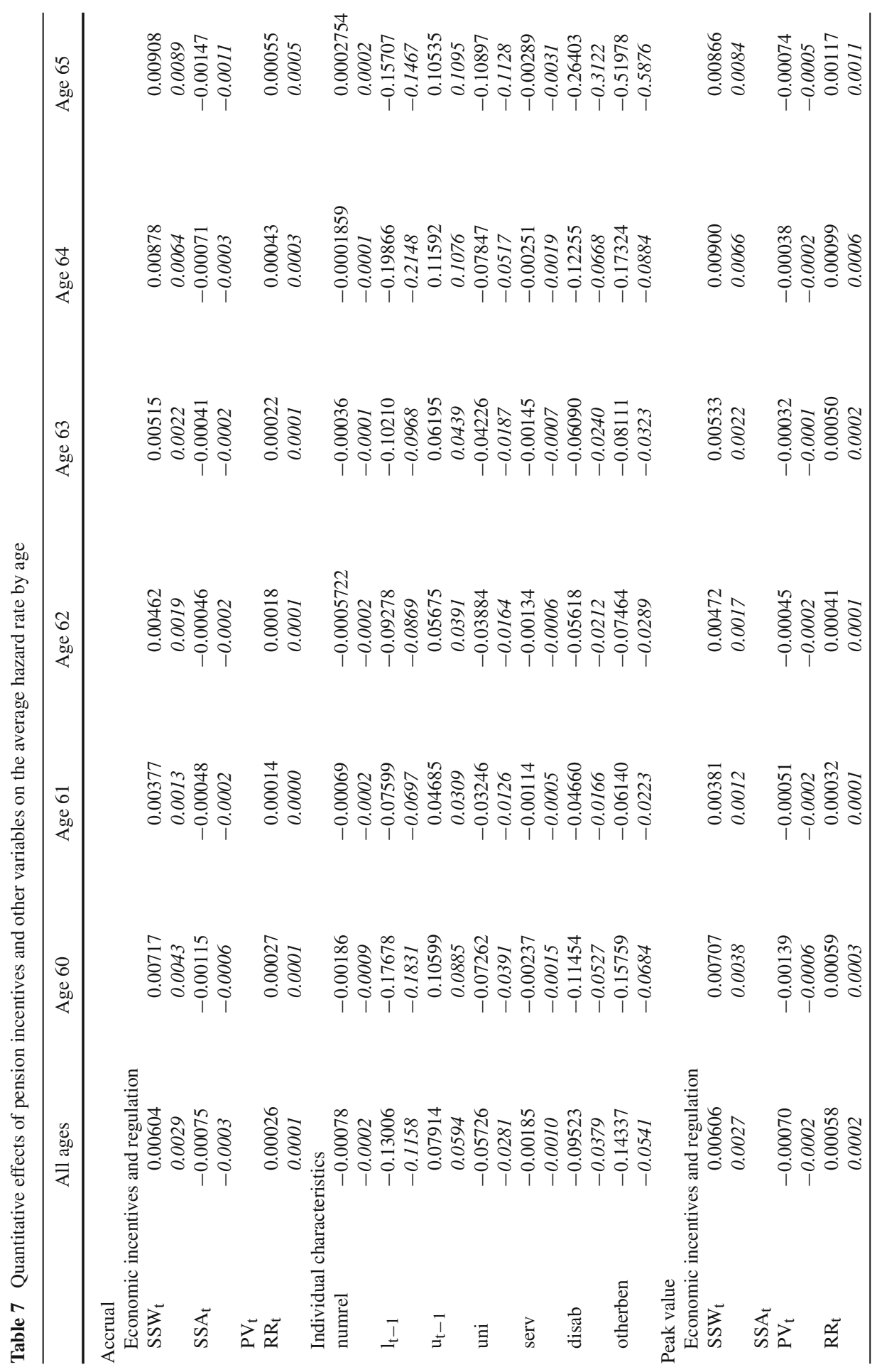




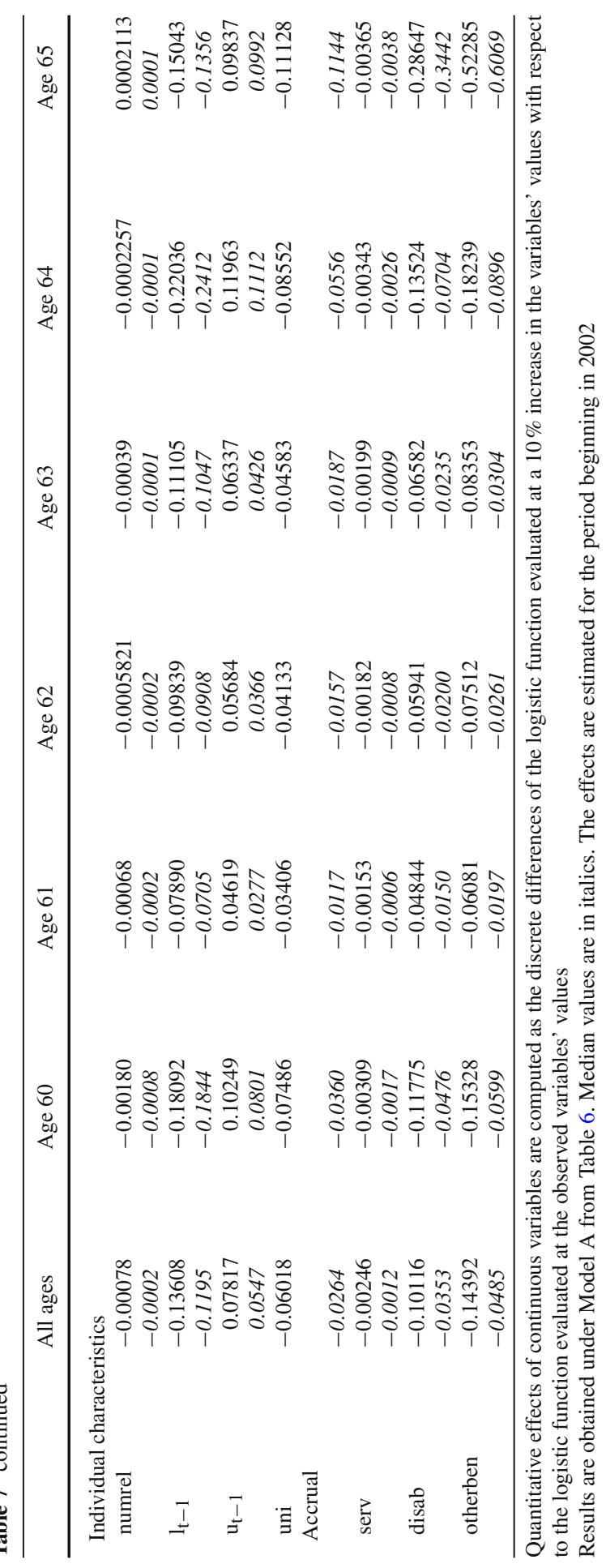




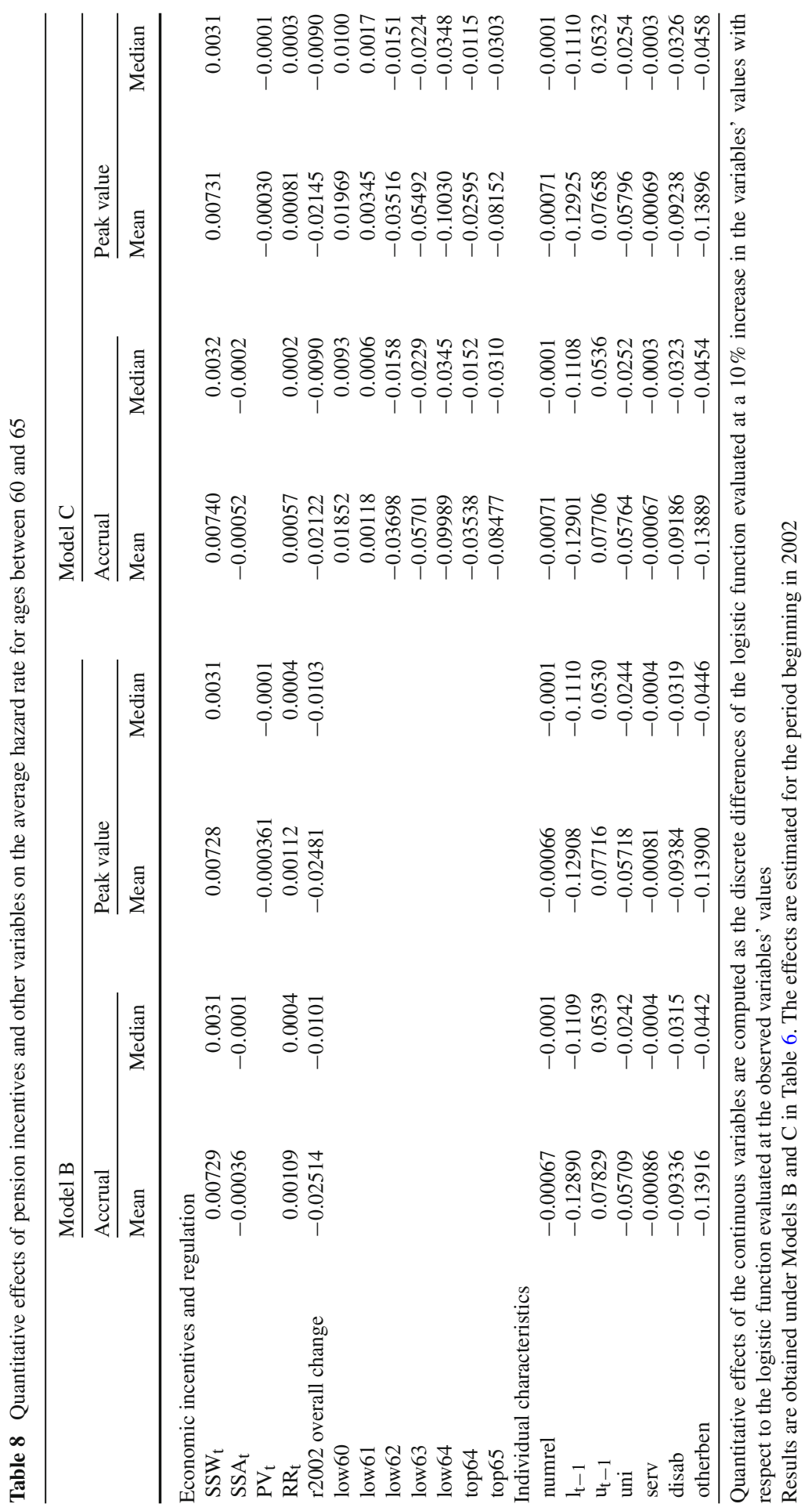




\section{References}

Ahn N, Mira P (2000) Labor Force Participation and Retirement of Spanish Older Men: Trends and Prospects. (FEDEA, Ed.) FEDEA Working Paper (Working paper 2000-25)

Alba A (1997) Labour Market Participation and Transitions of Older Workers in Spain'. (Universidad Carlos III, Working Paper No 97-39)

Argimón I, González CI (2006) La Muestra Continua de Vidas Laborales de la Seguridad Social. (B. d. España., Ed.) Boletín Económico Banco de España

Argimón I, González CI, Vegas R (2007a) La situación laboral en las edades próximas a la jubilación. Una explotación de la Muestra Continua de Vidas Laborales. (B. d. España, Ed.) Boletín Económico Banco de España

Argimón I, González CI, Vegas R (2007b) Jubilacion entre los 60 y los 65 años. Algunas características. Presupuesto y Gasto Público, 47-(2/2007), pp 161-184

Balmaseda M, Melguizo A, Taguas D (2006) Reforming the Spanish contributory pensions system. MPRA Paper 19574, University Library of Munich, Germany, revised 01 Mar 2006

Barea J (1996) Escenarios de evolución del gasto público en pensiones y desempleo en el horizonte 2020. Documentos de Economía Pública, Fundación BBVA

Blanco A (2000) The decision of early retirement in Spain. FEDEA, EEE 76

Blundell R, Meghir C, Smiths S (2002) Pension incentives and the pattern of early retirement. Econ J 112:153-170

Boldrin M, Jimenez-Martín S, Peracchi F (1999) Social security and retirement in Spain. NBER papers. In: Gruber J, Wise D (eds) Social security programs and retirement around the World, pp 305-353. The University of Chicago Press, Chicago

Boldrin M, Jimenez-Martín S, Peracchi F (2004) Micro-modelling of retirement behaviour in Spain. In: Gruber J, Wise D (eds) Social Security programs and retirement around the world. Micro-estimation, pp 499-578. The University of Chicago Press, Chicago

Boldrin M, Jimenez-Martín S (2007) Evaluating Spanish Pension Expenditure under Alternative Reform Scenarios, NBER Chapters In: Social Security Programs and Retirement around the World: Fiscal Implications of Reform. National Bureau of Economic Research, Inc., pp 351-412

Bover O, Arellano M, Bentolila S (2002) Unemployment duration, benefit duration and the business cycle. Econ J 112:223-265

Burtless G (1986) Social Security, unanticipated benefit increases and the timing of retirement. Rev Econ Stud 53:781-805

Cairó-Blanco I (2010) An empirical analysis of retirement behaviour in Spain: partial versus full retirement. SERIEs 2010(1):325-356. doi:10.1007/s13209-009-0009-4

Coile C, Gruber J (2000) Social Security Incentives for Retirement. National Bureau of Economic Research, Inc., Working Paper 7651

Conde-Ruiz JI, Galasso V (2003) Early retirement. Rev Econ Dyn 2:12-36

Conde-Ruiz JI, García E (2004) Demografía y empleo de los trabajadores próximos a la jubilación en Cataluña. FEDEA Documento de, Trabajo 2004-29

Conde-Ruiz JI, González CI (2012) Spain 2011 Pension Reform. Working Paper 2012-03, FEDEA

Díaz-Gimenez J, Díaz-Saavedra J (2009a) Delaying retirement in Spain. Rev Econ Dyn 12(1):147-167

Díaz-Gimenez J, Díaz-Saavedra J (2009b) Las pensiones públicas en España: una reforma que no funciona. Documento de Trabajo Unicaja, Premio de Investigación Economica Unicaja

García-Pérez JI, Sánchez-Martín AR (2008a) Social Security and the search behaviour of workers approaching retirement. Working Paper. Universidad Pablo Olavide. Econ 0803

García-Pérez JI, Sánchez-Martín AR (2008b) Jubilación y búsqueda de empleo a edades avanzadas. Actual 33. Fundación Centro de Estudios Avanzados. Centro de Estudios Andaluces

Gómez A, Hernandez de Cos P (2004) An introductory analysis of the incentives for old workers to abandon the labour market. Mimeo

Gruber J, Wise D (1999) Social Security programs around the world. University of Chicago Press, Chicago

Gruber J, Wise D (2004) Social Security programs and retirement around the world. Micro-estimation. University of Chicago Press, Chicago

Gustman AL, Steinmeier TL (2004) Social security, pension and retirement behaviour within the family. J Appl Econ 19:723-737

Gustman AL, Steinmeier TL (2008) Projecting behavioral responses to the next generation of retirement policies. Res Labor Econ 28:141-196 
Gutiérrez-Domènech M (2006) The employment of older workers. Working Paper No. 04/2006. La Caixa

Herce JA, Alonso-Messeguer J (1999) Creación de Empleo y déficit del sistema de pensiones. Cuadernos Económicos del ICE, 65

Herce JA, García E, Jimeno JF (2005) La reforma de las pensiones: el papel de los mercados financieros. Fundación Caixa Galicia-CIEF

Herce JA, Fernandez-Pérez JL, Martín-Barragán E, Chuliá-Rodrigo E, Macmanus P, Alonso-Talon P (2009) Los retos socio-económicos del envejecimiento en España Resumen y conclusiones. Analistas Financieros Internacionales, AFI, Madrid

Imrohoroglu A, Imrohoroglu S, Joines D (1999) Computing models of social security. In: Marimón R, Scott A (eds), Computational methods for the study of dynamic economies

Jimenez-Martín S (2006) Evaluating the labor supply effects of alternative reforms of the Spanish pension system. Moneda y Crédito no 222:271-312

Jimenez-Martín S, Sánchez A (2000) Incentivos y reglas de jubilación en España. Cuadernos Económicos de ICE. No 65:45-88

Jimenez-Martín S, Sánchez A (2007) An evaluation of the life-cycle effects of minimum pensions on retirement behaviour. J Appl Econ 22(5):923-950

Jimenez-Martín S, Labeaga JM, Vilaplana-Prieto C (2006) A sequential model of older workers' labor force transitions after a health shock. Health Econ 15:1033-1054

Jimeno JF (2001) El sistema de pensiones contributivas en España: Cuestiones básicas y perspectivas en el medio plazo. Nuevas Fronteras de la Política Económica, 2000. CREÍ, Teresa Garcia-Milá editor

Jimeno JF, Licandro O (1999) La Tasa interna de rentabilidad y equilibrio financiero del sistema español de pensiones de jubilación. Invest Econ XXIII(1):129-143

Labeaga J (2008) Estudios sobre las decisiones de retiro, la sostenibilidad del sistema de pensiones en España y la viabilidad financiera del Sistema Nacional de Dependencia. Colección Estudios Económicos 04-08 Cátedra Nuevos Consumidores/FEDEA-BB

Lopez-Garcia M (1990) Efectos de las pensiones de Seguridad Social sobre la oferta de trabajo en España: un comentario. Invest Econ XXIV(2):305-310

Martín A, Moreno L (1990) Efecto de las pensiones de la Seguridad Social sobre la oferta de trabajo en España. Invest Econ XXIV:291-303

Martínez F (1999) Historiales de la Seguridad Social. Universidad Carlos III, Mimeo

Messeguer J (2006) La contribuitividad y el desequilibrio actuarial de las pensiones de jubilación en España. En La Reforma de las Pensiones: Europa, Latinoamerica y España, Vol. 4. Panorama Social, Segundo Trimestre, pp 76-86

Montero-Muñoz M (2000) Estructura demográfica y pensiones un análisis de equilibrio general aplicado a la economía española. Invest Econ XXIV(2):297-327

Montizaan R, Cörvers F, De Grip A (2007) Training and early retirement. Research Centre for Education and the Labour Market. ROA-RM-2007/3, July 07. The Netherlands

Moral-Arce I, Patxot C, Souto G (2009) Fostering the contributory nature of the Spanish Retirement Pension System: an arithmetic microsimulation exercise using the MCVL. Instituto de Estudios Fiscales, Madrid

Muñoz J (1995) Un análisis de los determinantes de la edad de jubilación mediante modelos de duración. Documento de Trabajo 9523, CEMFI

Norton E, Wang H, Ai C (2004) Computing interaction effects and standard errors in logit and probit models. Stata J 4(2):154-167

Prieto Rodríguez J, Romero D, Álvarez S (2002) Estado de salud y participación laboral de las personas mayores. Cuadernos Aragoneses Econ 12(2):271-291

Samwick A (1998) New evidence on pensions, social security, and the timing of retirement. J Public Econ 70:207-236

Sánchez-Martín AR (2003) Jubilación endógena y sistema público de pensiones en España. Universidad Carlos III WE 072515

Sánchez-Martín AR (2010) Endogenous retirement and public pension system reform in Spain. Econ Modell 27:336-349

Sánchez-Martín AR, Sánchez-Marcos V (2008) Demographic change, pension reform and redistribution in Spain. Documento de Trabajo Fedea 2008-14 Serie Capital Humano y Empleo

Seguridad Social (2006) La muestra continua de vidas laborales. Colección informes y estudios, Serie Seguridad Social 24 
Utrilla De La Hoz A, Ubago Y (2005) Efectos redistributivos del sistema de pensiones de la Seguridad Social y factores determinantes de la elección de la edad de jubilación. Un análisis por Comunidades Autónomas. Papeles de Trabajo 3/05 Instituto de Estudios Fiscales. Madrid

Villagarcía T (1995) Análisis econométrico del tránsito a la jubilación par trabajadores en edad avanzada. Investigaciones Económicas. XIX(1):65-81

Whitehouse E, D'addioa A, Chomika R, Reilly A (2009) The future of pensions and retirement income two decades of pension reform: what has been achieved and what remains to be done. Geneva Pap $34: 515-535$ 